\title{
Chapter 1 \\ Antiviral Silencing and Suppression of Gene Silencing in Plants
}

\author{
Tibor Csorba and József Burgyán
}

\begin{abstract}
RNA silencing is an evolutionary conserved sequence-specific gene inactivation mechanism that contributes to the control of development, maintains heterochromatin, acts in stress responses, DNA repair and defends against invading nucleic acids like transposons and viruses. In plants RNA silencing functions as one of the main immune systems. RNA silencing process involves the small RNAs and trans factor components like Dicers, Argonautes and RNA-dependent RNA polymerases. To deal with host antiviral silencing responses viruses evolved mechanisms to avoid or counteract this, most notably through expression of viral suppressors of RNA silencing. Due to the overlap between endogenous and antiviral silencing pathways while blocking antiviral pathways viruses also impact endogenous silencing processes. Here we provide an overview of antiviral silencing pathway, host factors implicated in it and the crosstalk between antiviral and endogenous branches of silencing. We summarize the current status of knowledge about the viral counter-defense strategies acting at various steps during virus infection in plants with the focus on representative, well studied silencing suppressor proteins. Finally we discuss future challenges of the antiviral silencing and counter-defense research field.
\end{abstract}

Keywords RNA silencing • Virus infection • Antiviral defense • Silencing suppressor strategies $\bullet$ Host-pathogen interaction

\subsection{RNA Silencing}

\subsubsection{Introduction}

RNA silencing is a sequence-specific gene-inactivation mechanism conserved from lower eukaryotes to mammals (Shabalina and Koonin 2008; Weiberg and Jin 2015). RNA silencing, also known as RNA interference (RNAi), has diverse functions

T. Csorba $(\bowtie) \cdot$ J. Burgyán

National Agricultural Research and Innovation Center - Agricultural Biotechnology Center

(NARIC-ABC), Gödöllő, Szent-Györgyi A. u. 4, Pest 2100, Hungary

e-mail: csorba@abc.hu 
including growth and developmental regulation, DNA repair, biotic and abiotic stress response or host immunity against invading nucleic acids like transposons or viruses (Castel and Martienssen 2013; Martinez de Alba et al. 2013; Pumplin and Voinnet 2013). The trademark molecules of silencing are the small RNAs (sRNAs) (Hamilton and Baulcombe 1999) of 21-24 nt length. These guide the sequencespecific effector steps either at transcriptional or at post-transcriptional levels. During transcriptional gene silencing (TGS) target genes are inhibited by epigenetic modification of chromatin (e.g histone protein post-translational modifications and DNA methylation) (Castel and Martienssen 2013) while during post-transcriptional gene silencing (PTGS) gene inactivation occurs through mRNA cleavage or translational repression (Martinez de Alba et al. 2013). Depending on the sRNA type and effector proteins involved, silencing pathways provide diverse and dedicated functions.

\subsubsection{Biochemical Framework of Silencing}

RNA silencing process can be partitioned mechanistically into three distinct phases: initiation phase, effector phase and in some specific circumstances amplification phase. Most of the knowledge comes from the model plant Arabidopsis thaliana, therefore the nomenclature of components relays on these components.

\subsubsection{Initiation of Silencing}

Initiation of silencing comprises of two main steps: biogenesis of sRNAs and their loading into effector complexes. The trigger of silencing initiation is always a double-stranded RNA (dsRNA) molecule present within the cell: perfect or imperfect dsRNA structures can be formed by single-stranded RNA (ssRNA) transcripts folding into a hairpin secondary structure, may come from the inter-molecular interaction of two partially reverse complementary single-stranded RNAs (ssRNAs) produced either by convergent transcription from the sense and antisense strands of the loci (in cis) or by pairing of homologue regions of transcripts originating from different loci (in trans). Alternatively, perfectly complementary dsRNAs may arise as the product of RNA-dependent RNA polymerases by conversion of ssRNA molecules into dsRNAs. The dsRNA molecules/regions are recognized by a member of the RNase III type enzyme family DICERS, in plants named DICER-LIKE proteins, (DCLs, in Arabidopsis DCL1-4) (Bernstein et al. 2001; Hamilton and Baulcombe 1999; Hutvagner et al. 2001). DCLs contain a helicase, a PAZ, two RNase-III and two dsRNA-binding domains. The PAZ and RNA-binding domains position the dsRNA substrate in such a way that the two RNase-III pseudo-dimers catalyzes processing of the dsRNA molecules/regions into sRNA duplexes of 21-24 nt lenght, with specific 2-nt-long $3^{\prime}$ overhangs (having 5'-P and $3^{\prime}$-OH ends). 
For the accurate and effective excision of sRNAs from their precursor molecules DCLs require cooperation of DOUBLE-STRANDED RNA BINDING proteins (DRB, in Arabidopsis DRB1-5). Sometimes specific DCL-DRB interaction is required for the transfer of sRNA duplex into specific effector complexes (Eamens et al. 2012a, b; Han et al. 2004; Hiraguri et al. 2005). Following processing, the sRNAs are stabilized at their $3^{\prime}$ end by the HUA Enhancer 1 (HEN1)-dependent $2^{\prime}$-O-methylation (a process found only in plants and flies so far) (Boutet et al. 2003; Yang et al. 2006) and exported from the nucleus to the cytoplasm by HASTY (HST), the homologue of mammalian exportin-5 (Bollman et al. 2003; Park et al. 2005; Peragine et al. 2004) to be loaded into effector complexes. It is believed that methylation may occur both in the nucleus and cytoplasm (Lozsa et al. 2008).

\subsubsection{Effector Phase of Silencing}

The essential catalytic components of effector complexes of silencing are the Argonaute proteins (AGOs, in Arabidopsis AGO1-10), RNase-H type endonucleases (Fagard et al. 2000; Hammond et al. 2001; Hutvagner and Simard 2008; Liu et al. 2004; Mallory and Vaucheret 2010). AGOs together with accessory proteins form the effector complex of silencing: the RNA-Induced Silencing Complex (RISC) that acts during PTGS (Lee et al. 2004; Pham et al. 2004; Tomari et al. 2004), or the RNA-Induced Transcriptional Silencing Complex (RITSC) that acts during TGS (Castel and Martienssen 2013; Ekwall 2004). RISC/RITSC assembly comprises of two clearly distinguishable steps: (i) loading of ds-sRNAs and (ii) unwinding of sRNAs (Kwak and Tomari 2012). Biogenesis and loading of ds-sRNAs seems to be coupled (at least in the case of miRNAs) (Reis et al. 2015). AGO-loading process requires Hsp70-Hsp90 chaperone machinery and ATP hydrolysis to drive AGO conformational changes. The size and the $5^{\prime}$ nucleotide type contributes to the sorting of sRNAs into specific AGO partners (e.g 21-nt-long 5' U sRNAs are preferentially loaded into AGO1 etc.) (Mallory and Vaucheret 2010). The strand having less stable $5^{\prime}$-end pairing (within the ds-sRNA molecule) is retained within the AGO while the other, the so-called "star" strand is eliminated (Khvorova et al. 2003; Schwarz et al. 2003). Guided by the sRNA sequence, RISC induces slicing or translational repression of its target RNAs (during PTGS) in a sequence-specific manner (Brodersen and Voinnet 2009; Kim et al. 2014). The cleavage products of RISC are eliminated by the general mRNA decay and quality control machinery present within the cell (Martinez de Alba et al. 2015; Parent et al. 2015b; Ren et al. 2014; Souret et al. 2004; Yu et al. 2015). RITSC complex causes histone and/or DNA methylation, resulting in transcriptional gene silencing (TGS) of the homologous gene (Castel and Martienssen 2013; Creamer and Partridge 2011). AGO1, 2, 3, 5, 7 and 10 have roles in PTGS while AGO4, 6 and 9 are involved in TGS (AGO8 is considered as pseudo-gene) (Mallory and Vaucheret 2010). 


\subsubsection{Amplification of Silencing}

Cytoplasmic RNA silencing may be activated also by the presence of RNAs having aberrant features (without CAP-structure, lacking polyA tail etc.) or endonucleolytically cleaved RISC fragments. RNA-DEPENDENT RNA POLYMERASES (RDRs, in Arabidopsis RDR1, 2, 3a, 3b, 3c and 6) (Wassenegger and Krczal 2006) protein recognize these molecules as their substrates and convert them into dsRNAs that enter/re-enter into silencing through DCL-mediated sRNA production. RDR6 is the main cytoplasmic enzyme to be involved in this process (Branscheid et al. 2015; Martinez de Alba et al. 2015; Mourrain et al. 2000; Parent et al. 2015b; Sijen et al. 2001; Vaistij et al. 2002; Voinnet et al. 1998). Usage of RISC cleavage products by RDRs results in amplification of silencing response that may have also non-cell-autonomous consequences.

AGO-mediated target cleavage and amplification by RDR enzymes are intimately linked in the nuclear TGS as well. RNA polymerase IV (PolIV, a plant specific polymerase) transcribes short precursor ssRNAs from loci to be silenced. RDR2 physically associates with PolIV to convert its transcripts into dsRNA. DCL3 cleaves the dsRNA to produce sRNAs that are loaded mainly into AGO4 (alternatively AGO6 or 9). AGO4 associates with accessory proteins to form RITSC. Guided by the sRNA, RITSC is tethered to nascent transcripts synthetized by RNA polymerase $\mathrm{V}$ (PolV) and induce silencing of the target loci by recruiting histone and/or DNA modification complexes (Castel and Martienssen 2013).

\subsubsection{Endogenous Pathway Diversification}

The combined activities of specific (sometimes partially redundant) trans factors of silencing (DCLs, DRBs, AGOs and RDRs) and the involvement of different sRNA precursor molecules result in parallel gene silencing pathways (Bologna and Voinnet 2014; Hiraguri et al. 2005; Mallory and Vaucheret 2010; Wassenegger and Krczal 2006). These pathways rely on various sRNAs like microRNAs (miRNAs), trans-acting small interfering RNAs (ta-siRNAs), natural-antisense RNAs (nat-siRNAs), repeat-associated siRNAs (ra-siRNAs), viral siRNAs (vsiRNAs) and virus-activated siRNAs (vasiRNAs) and provide dedicated functions/roles of silencing (Martinez de Alba et al. 2013).

\subsubsection{Systemic Silencing}

Amplification of RNA silencing has been implicated in the spread of an RNA silencing signal (Kalantidis et al. 2008; Molnar et al. 2010, 2011; Schwach et al. 2005). Small RNAs of 21-24 nt lengths generated during cell-autonomous 
RNA silencing spread from the site of initiation to the neighboring cells through plasmodesmata. Besides this, silencing signal is able to spread systemically over long distances through the phloem. The exact nature of silencing signal is not clear, although sRNAs are known to be involved; sRNAs may be associated with proteins (e.g AGOs) during translocation that could protect them against cellular nucleases. Mobile sRNAs, similarly to their cell-autonomous counterparts, are able to trigger transcriptional or post-transcriptional silencing. It was shown that silencing signal movement has roles in the formation of patterns within a tissue (e.g. leaf polarity) (Chitwood et al. 2009), contributes to the reinforcement of transposon silencing in generative cells (Borges et al. 2011; Slotkin et al. 2009), initiate epigenetic events during genome defense (Cui and Cao 2014) and respond to external stimuli (Katiyar-Agarwal et al. 2006). Silencing signal movement has also important implication in antiviral defense and plant recovery (Havelda et al. 2003; Szittya et al. 2002).

\subsection{Antiviral Roles of RNA Silencing}

\subsubsection{Introduction}

The antiviral function of RNA silencing was demonstrated in plants and invertebrates (Bronkhorst and van Rij 2014; Pumplin and Voinnet 2013). Recent reports have provided evidence that antiviral silencing also operates in mammals, especially in ESC cells, however its role still remains controversial (Castel and Martienssen 2013; Cullen et al. 2013; Maillard et al. 2013). Is it believed that the ancient function of silencing was the antiviral defense itself (Pumplin and Voinnet 2013; Wang and Metzlaff 2005). Specific members of DCL's, DRB's, AGO's, and RDR's contribute to the antiviral pathway during the various host-virus combinations (see Table 1.1 and relevant references within).

\subsubsection{Biogenesis of vsiRNAs}

As one of the first sRNA type discovered, the existence of vsiRNAs provided the first hint that silencing may have antiviral roles (Hamilton and Baulcombe 1999). Biogenesis of vsiRNAs requires DCL enzymes. Viral substrate molecules for DCLs vary depending on the virus replication strategy. In case of RNA viruses the highly structured fold-back regions of viral single-stranded RNAs (ssRNA) and replicative intermediates (RI) may be the primary source of vsiRNA production (Ahlquist 2002; Donaire et al. 2009; Molnar et al. 2005; Szittya et al. 2010; Kontra et al. unpublished). In case of DNA viruses the overlapping convergent/bidirectional read-through transcripts or fold-back structure of specific regions of RNA 


\begin{tabular}{|c|c|c|c|c|c|c|c|c|c|c|c|c|c|c|}
\hline 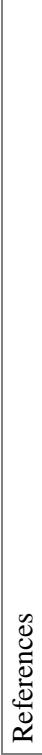 & 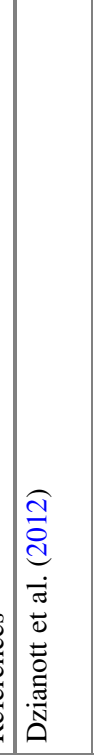 & 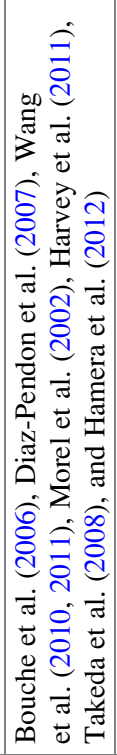 & 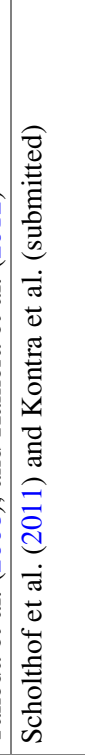 & 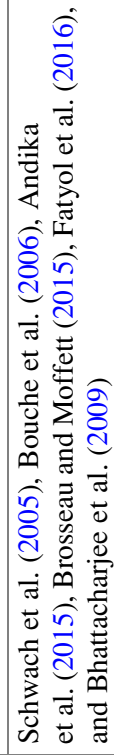 & 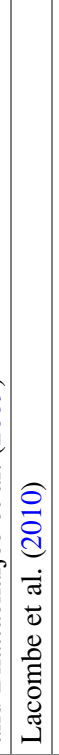 & 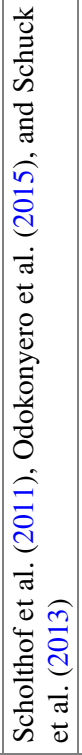 & 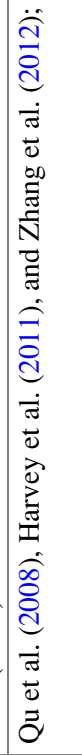 & 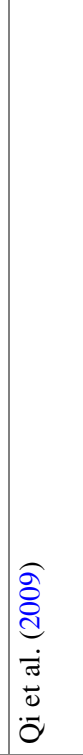 & 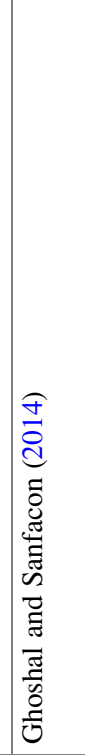 & 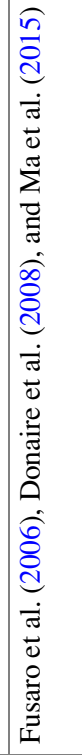 & 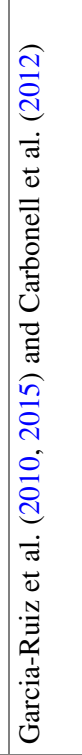 & 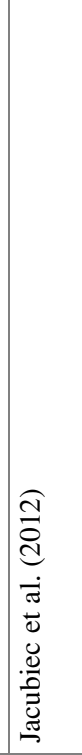 & 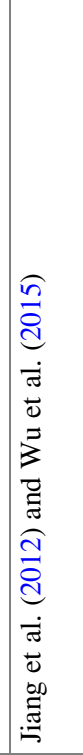 & 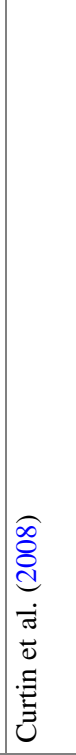 \\
\hline 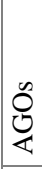 & O্ & 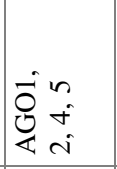 & 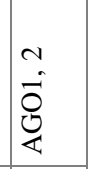 & 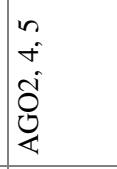 & & 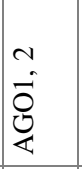 & 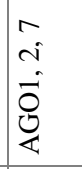 & & 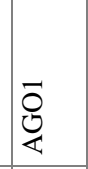 & 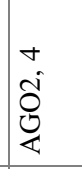 & 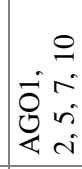 & & 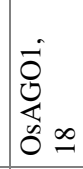 & \\
\hline$\frac{\tilde{v}}{2}$ & 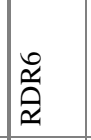 & $\begin{array}{l}0 \\
\dot{a} \\
\text { ح̂. }\end{array}$ & & $\begin{array}{l}2 \\
\frac{1}{2} \\
\underline{\alpha}\end{array}$ & & & & 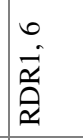 & & $\begin{array}{ll}\overrightarrow{\hat{\alpha}} & 0 \\
\text { حิ } & i\end{array}$ & 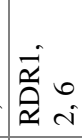 & & $\begin{array}{l}\text { Q } \\
\text { aี } \\
\text { حิ }\end{array}$ & \\
\hline $\begin{array}{l}\tilde{n} \\
\tilde{a}\end{array}$ & & & & & & & 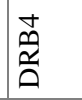 & & & & & 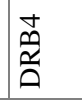 & & 吉 \\
\hline ڤึ & 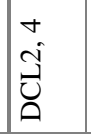 & 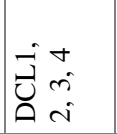 & & 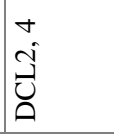 & 声 & & 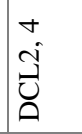 & & & चُ & 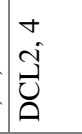 & 莳 & & 莳 \\
\hline $\begin{array}{l}\overline{\vec{v}} \\
\stackrel{0}{1}\end{array}$ & 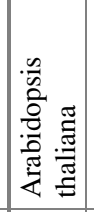 & 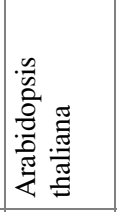 & 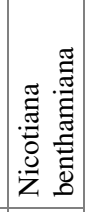 & 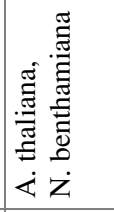 & 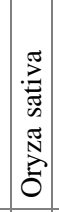 & 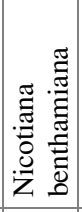 & 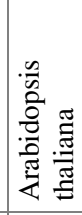 & 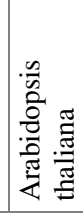 & 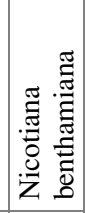 & 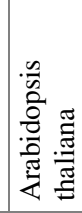 & 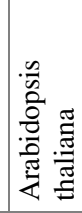 & 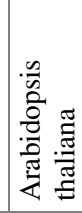 & 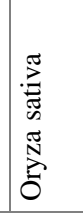 & 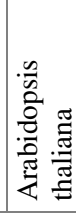 \\
\hline$\sum_{\bar{\nu}}^{0}$ & $\sum_{\infty}$ & $\sum_{U}^{Z}$ & 点 & $\stackrel{x}{a}$ & $\sum_{\substack{c \\
c}}^{Z}$ & $\begin{array}{l}\vec{b} \\
n \\
0 \\
1\end{array}$ & 党 & $\sum_{i}$ & 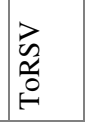 & 齐 & $\sum_{E}$ & $\sum_{\lambda}^{\lambda}$ & $\vec{n}$ & $\sum_{3}^{3}$ \\
\hline & 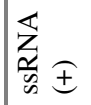 & & & & & & & & & & & & 岁 & \\
\hline
\end{tabular}




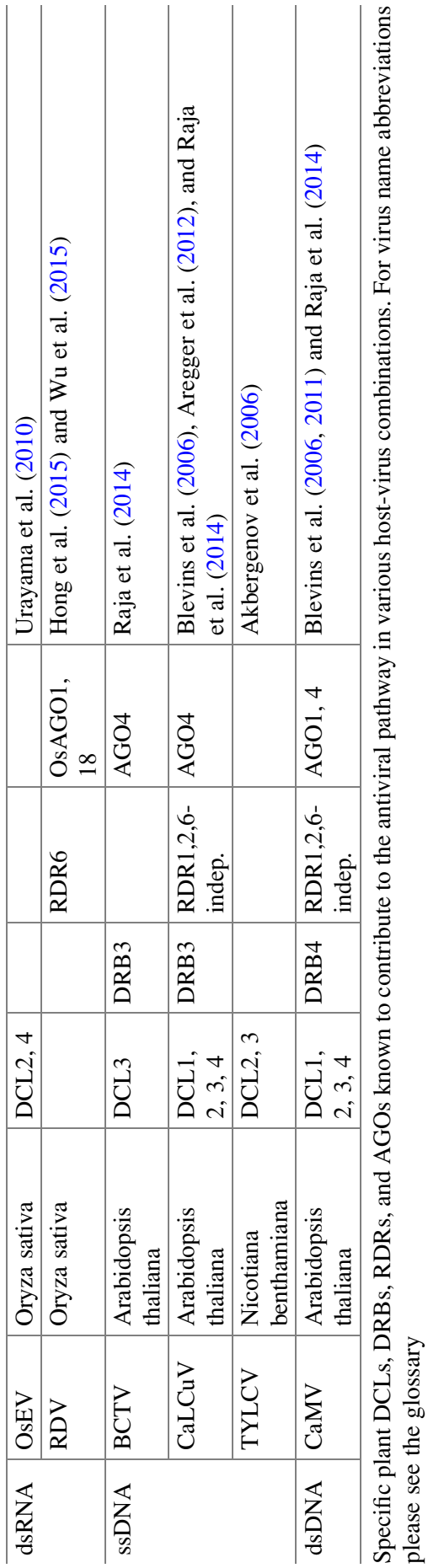


transcripts contribute to vsiRNA biogenesis (Akbergenov et al. 2006; Aregger et al. 2012; Blevins et al. 2006, 2011; ; Chellappan et al. 2004) (Fig. 1.1). Genetic studies and deep sequencing analysis of vsiRNAs involving Arabidopsis dcl mutants revealed that a strong hierarchy exists between DCLs regarding their contribution to vsiRNA production. The main DCL in case of RNA virus infections is the DCL4 while DCL2 becomes critical in its absence (in $d c l 4$ mutant) (Andika

a

RNA viruses

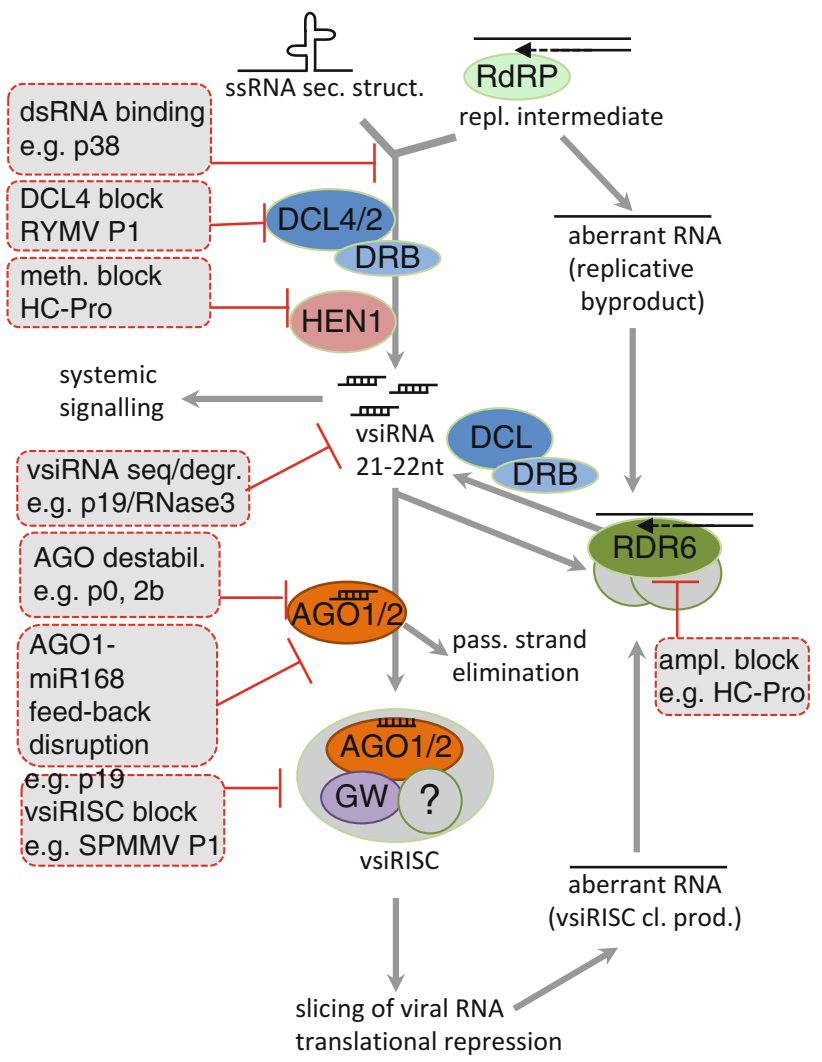

Fig. 1.1 Biochemical framework of antiviral RNA silencing and its suppression by VSRs. Antiviral RNA silencing is initiated by the recognition of viral dsRNA structures (replicative intermediate, partially double-stranded fold-back structures or overlapping RNA transcript pairing), which are processed into viral siRNAs (vsiRNAs) by Dicer-like proteins (DCLs). Subsequently vsiRNAs $21-22$ nt or 24 nt long are incorporated into effector complexes RNA-induced silencing complex (RISC) or RNA-Induced transcriptional Silencing Complex (RITSC), respectively. Question mark represents unknown cofactors. The vsiRISC targets viral RNAs by slicing or translational inhibition (a), while RITSC induces genome modification (b). Cleavage producs and vsiRNA may enter an amplification loop through the actions of RNA-dependent RNA polymerases (RDRs) and cofactors (SGS3 and SDE5) to give rise of secondary vsiRNAs. Antiviral silencing pathway may be halted at various points by viral silencing suppressors (VSRs) (a and b) (dash-line boxes) 
b

DNA viruses

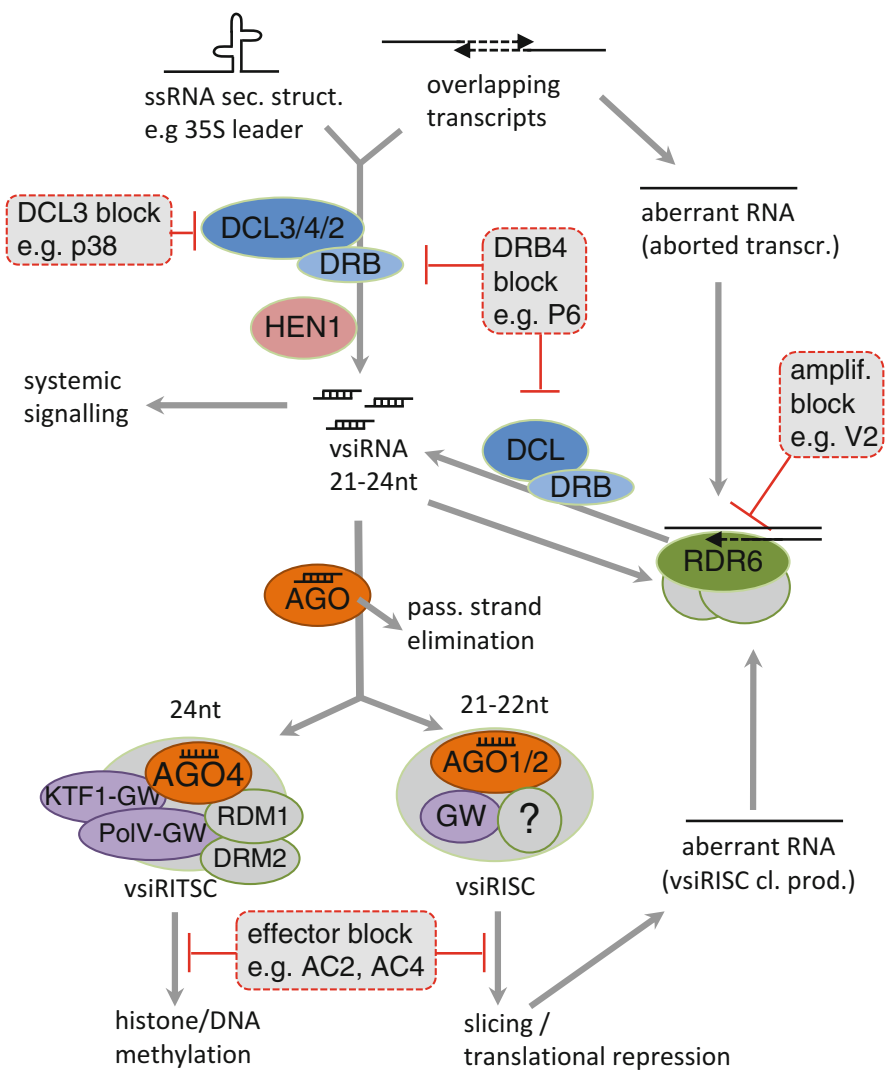

Fig. 1.1 (continued)

et al. 2015; Deleris et al. 2006; Donaire et al. 2009; Dzianott et al. 2012; GarciaRuiz et al. 2010; Qu et al. 2008; Urayama et al. 2010). Additional functional diversity between DCL4 and DCL2 has been reported: DCL2 stimulates transitivity and secondary siRNA production, while DCL4 is sufficient for silencing on its own (Parent et al. 2015a). DCL3 has only a minor role against RNA viruses (Qu et al. 2008; Raja et al. 2014). The fact that silencing suppressors of RNA viruses interfere with DCL3 pathway suggests that DCL3 contributes to antiviral silencing (Azevedo et al. 2010; Hamera et al. 2012; Lacombe et al. 2010). During antiviral silencing against DNA viruses DCL3 is essential and works presumably by inducing chromatin modifications (Akbergenov et al. 2006; Blevins et al. 2006; Raja et al. 2014). DCL1 may act as a negative regulator limiting DCL4 and DCL3 through miRNA pathway (Azevedo et al. 2010; Qu et al. 2008).

DCLs' cofactors, the DRB proteins are also required for vsiRNA biogenesis. DRB4, the cofactor of DCL4, takes part in antiviral defense against RNA viruses (Curtin et al. 2008; Jakubiec et al. 2012; Qu et al. 2008). The observation that P6 
silencing suppressor of Cauliflower mosaic virus (CaMV) inhibits DRB4, strongly suggests that DRB4 is an antiviral factor against DNA viruses as well. DRB3, the cofactor of DCL3, contributes to antiviral defense through chromatin modification against DNA viruses (Raja et al. 2014).

HEN1-mediated vsiRNA methylation is critical for effective antiviral defense (Vogler et al. 2007). henl mutants are more susceptible to Cucumber mosaic virus (CMV) and Turnip crinkle virus (TCV) virus infections (Boutet et al. 2003; Zhang et al. 2012). vsiRNA-binding viral silencing suppressor were shown to inhibit methylation (Csorba et al. 2007; Lozsa et al. 2008).

\subsubsection{Effector Step of Antiviral Silencing}

Dicing per se is not sufficient for an efficient antiviral silencing response (Wang et al. 2011), suggesting that the DCLs' substrates may be only the byproducts of the viral replication process. vsiRNA-binding VSRs do not compromise dicing, but efficiently inhibit antiviral silencing (Csorba et al. 2015). The downstream AGO-dependent effector step is therefore necessary to restrict virus replication and spread of both RNA and DNA viruses (Azevedo et al. 2010; Carbonell et al. 2012; Harvey et al. 2011; Pantaleo et al. 2007; Qu et al. 2008; Raja et al. 2014; Raja et al. 2008; Wang et al. 2011). The properties of vsiRNAs like 5 '-nucleotide, length, thermodynamical properties of sRNA duplex ends and sRNA's duplex structure define loading and sorting into AGO effectors (Khvorova et al. 2003; Mi et al. 2008; Schuck et al. 2013; Schwarz et al. 2003; Zhang et al. 2014; Kontra et al. unpublished). During RNA virus infections AGO1 and $\mathrm{AGO} 2$ are the most important effectors, while AGO5, 7, 10 may have additional roles or act during specific host-virus combinations (Carbonell and Carrington 2015) (Fig. 1.1).

AGO1 was identified as the main effector against Brome mosaic virus (BMV), CMV, TCV, Turnip mosaic virus (TuMV) in Arabidopsis thaliana (Dzianott et al. 2012; Garcia-Ruiz et al. 2015; Morel et al. 2002). AGO1 participate in removal of TuMV viral RNA through slicing activity (Carbonell et al. 2012). AGO1 translational repression activity was also found to play a role during Tomato ringspot virus (ToRSV) infection in Nicotiana benthamiana (Ghoshal and Sanfacon 2014). It was shown that during RNA virus infections AGO1 homeostasis (Mallory et al. 2008) is disrupted and AGO1 protein levels are decreased probably through translational repression of AGO1 mRNA by miR168 activity (Varallyay et al. 2010). Arabidopsis agol and ago2 mutants are hypersusceptible to CMV, TuMV and TCV (Carbonell et al. 2012; Harvey et al. 2011; Morel et al. 2002; Takeda et al. 2008). As AGO1 is the negative regulator of AGO2 through miR403 action, in the absence of AGO1 activity AGO2 levels are elevated (Azevedo et al. 2010; Harvey et al. 2011). AGO2 therefore emerges as a second layer in antiviral pathways. AGO2 was shown to be important in defense against CMV, TCV and Potato virus X (PVX) viruses in A. thaliana (Brosseau and Moffett 2015; 
Harvey et al. 2011; Jaubert et al. 2011). The phenotype of agolago2 double mutant indicates that the two proteins act in a synergistic manner and have non-overlapping functions, as suggested by their phylogenetic distance (Mallory and Vaucheret 2010; Wang et al. 2011).

Our knowledge about the function of AGO proteins during PTGS in species other than Arabidopsis is much limited due to lack of genetic tools. In $N$. benthamiana it was shown that AGO2 protects against TBSV, TMV, PVX, Cucumber necrosis virus (CNV) and Cymbidium ringspot virus (CymRSV) (Fatyol et al. 2016; Odokonyero et al. 2015; Scholthof et al. 2011). Recently, however AGO1 was proposed to be the essential effector against CymRSV (Kontra et al., unpublished) and is also required for recovery during ToRSV infection (Ghoshal and Sanfacon 2014).

In rice there are 19 AGOs categorized into four clades (Nonomura et al. 2007). Genetic and biochemical data suggest that in rice the AGO1 and AGO18 are the main antiviral effectors against Rice stripe virus (RSV), Rice dwarf phytoreovirus (RDV) (Hong et al. 2015; Jiang et al. 2012; Wu et al. 2015). AGO18 is induced during virus infection and may confer a broad-spectrum resistance: AGO18 do not bind efficiently vsiRNAs, instead, by sequestration of miR168 it interferes with AGO1 homeostasis. This action leads to elevated levels of AGO1 required for antiviral defense (Wu et al. 2015).

Effectors AGO4, 5, 7 and 10 were also proposed to possess additional antiviral roles against RNA viruses. CMV $2 \mathrm{~b}$ silencing suppressor protein directly interacts with AGO4 and inhibits its slicer activity and methylation and thus creates a favorable niche for CMV proliferation (Hamera et al. 2012). AGO5 (besides AGO2) was shown to be required to inhibit PVX systemic infection (Brosseau and Moffett 2015). AGO7 seems to work as a surrogate of AGO1 but with a preference for the less structured RNA targets (Qu et al. 2008; Takeda et al. 2008). AGO5, 7 and 10 had minor contribution in leaves while AGO10 (alongside AGO1) had antiviral functions in inflorescence during systemic TuMV infection (Garcia-Ruiz et al. 2015).

The nuclear localized AGO4 has been shown to possess important antiviral functions against geminiviruses. Arabidopsis $d c l 3, d r b 3$ and ago4 mutants fail to hypermethylate the viral genome that is required for host recovery (Raja et al. 2014). Besides, AGO4 was proposed to be important in transcriptional regulation of host transcriptional response during CMV virus infection (Hamera et al. 2012) or to be involved in PVX virus resistance induced by NB-LRR proteins involving AGO4-mediated translational control (Bhattacharjee et al. 2009).

AGOs loaded with vsiRNAs are able to form high molecular weight complexes (Csorba et al. 2010; Pantaleo et al. 2007). The knowledge about RISC (including antiviral RISC, vsiRISC) cofactors that cooperate with AGOs in plants is very limited (Omarov et al. 2016). Heat shock protein 70 and 90 (HSP70, HSP90) have been found to be important players in AGO loading by using an in vitro cell-free system that recapitulates the loading process (Iki et al. 2010). Further understanding of RISC components, assembly and function may be helped by in vitro and transient 
sensor systems (Fatyol et al. 2016; Iki et al. 2010; Omarov et al. 2016; Schuck et al. 2013).

\subsubsection{Amplification of Silencing}

To achieve a robust silencing response RISC cleavage fragments sometimes are channeled back into silencing by RDR-mediated dsRNA synthesis (Bologna and Voinnet 2014; Wassenegger and Krczal 2006). Subsequently to the AGO endonucleolytic cleavage, ssRNA fragments lacking bona fide features like cap structure or polyA tail are recognized by RDR polymerases with or without the help of primary vsiRNA and converted into long dsRNAs that are substrates of DCLs (Gazzani et al. 2004; Moreno et al. 2013; Parent et al. 2015b) (Fig. 1.1). RDR1, RDR2 and RDR6 (SDE1/SGS2) were all found to be important factors in vsiRNA production during PVX, CMV, TMV, Sugarcane mosaic virus (SCMV), TuMV, Tobacco rattle virus (TRV) infections (Diaz-Pendon et al. 2007; Donaire et al. 2008; Garcia-Ruiz et al. 2010; Qu et al. 2008; Schwach et al. 2005). RDR-synthetized dsRNAs are processed by DCL4 and DCL2 into 21-22 nt long vsiRNAs, respectively. Both 21 and 22 nt long vsiRNA were effective in antiviral response against a number of viruses like $\mathrm{CMV}$, Oilseed rape mosaic virus (ORMV), TCV, TRV, Cabbage leaf curl virus (CaLCuV), CaMV (Blevins et al. 2006; Bouche et al. 2006; Deleris et al. 2006; Donaire et al. 2008). 22 nt long vsiRNAs contribute to secondary siRNA production and mediate systemic silencing (Garcia-Ruiz et al. 2010; Wang et al. 2011). In case of robustly replicating RNA viruses the involvement of RDRs seems to be less important. Upon tombusvirus infection the major part of vsiRNAs derives from the positive RNA strand of the virus genome suggesting that they are primary DCL cleavage products of viral RNA fold-back structures (Aregger et al. 2012; Blevins et al. 2011; Donaire et al. 2008; Molnar et al. 2005; Szittya et al. 2010; Kontra et al. unpublished). In a similarly RDR-independent manner, massive amount of hairpin-derived vsiRNAs are produced from 35S leader of CaMV (Blevins et al. 2011). The majority of viral siRNAs accumulating during $\mathrm{CaLCuV}$ geminivirus infection were RDR1/2/6independent primary siRNAs generated by pairing of bidirectional read-through transcripts of the circular viral genome (Aregger et al. 2012).

RDR6 activity is facilitated by protein cofactors SUPPRESSOR OF GENE SILENCINIG 3 (SGS3) (Mourrain et al. 2000), SILENCING DEFECTIVE 5 (SDE5) (Hernandez-Pinzon et al. 2007) and SILENCING DEFECTIVE 3 (SDE3) (Dalmay et al. 2001). SGS3, a plant specific protein associate to RISC complex (Allen et al. 2005; Yoshikawa et al. 2005), stabilizes the RISC-cleavage products following slicing and enhance their conversion into dsRNA by RDR6 (Yoshikawa et al. 2013). Elimination of SGS3 leads to enhanced susceptibility to CMV but not to TuMV or Turnip vein-clearing virus (TVCV) infections (Adenot et al. 2006; Yoshikawa et al. 2013). SGS3 was shown to be required for CaLCuV virus induced VIGS of endogenous genes and was further suggested to be involved 
in the antiviral response against DNA viruses (Muangsan et al. 2004). This is supported by the fact that Tomato yellow leaf curl virus (TYLCV) encodes a silencing suppressor to compromise SGS3 activity (Glick et al. 2008). SDE5 is an RNA trafficking protein homologue of human mRNA export factor. SDE5 acts together with RDR6 to convert ssRNAs into dsRNA. sde5 mutant plants are hypersusceptible to CMV but not to TuMV infection (Hernandez-Pinzon et al. 2007). Silencing amplification is facilitated by the SDE3, an RNA-helicase like protein. SDE3 was shown to bind to AGOs through its GW domains (Garcia et al. 2012). sde3 mutant plants are more susceptible to CMV or PVX but not to TRV infections (Dalmay et al. 2001). SDE3 activity occurs downstream to RDR6 and requires AGO1 and AGO2 activities (Garcia et al. 2012). SDE3 was proposed therefore to facilitate the amplification process by unwinding a fraction of RDR6sythetized dsRNA products using helicase activity.

In rice there are five RDRs annotated, but our knowledge about their involvement in vsiRNA biogenesis is very limited. OsRDR6-silenced transgenic rice plants were shown to be hypersusceptible to RSV and RDV (Hong et al. 2015; Jiang et al. 2012). The rise in viral symptoms was associated with an increase in viral genomic RNA and reduced levels of vsiRNAs. Interestingly, the protein level of the overexpressed OsRDR6 in transgenic rice was reduced during RDV infection, suggesting a negative translational control induced by the virus upon RDR6 expression (Hong et al. 2015).

\subsection{Viral Silencing Suppressor Strategies}

\subsubsection{Introduction}

The most common strategy of viruses to protect themselves against antiviral RNA silencing is to express proteins that act as suppressors of silencing. These proteins are the viral suppressors of RNA silencing (VSRs). Discovery of VSRs provided a strong support of RNA silencing being an antiviral mechanism. Available evidences suggest that most viruses encode at least one VSR that, in most cases is essential for successful virus infection. Silencing suppression by VSRs has been described in insect and fungus-infecting viruses as well (Bronkhorst and van Rij 2014). Diversity of VSR's in sequence and structure indicates that they have evolved independently. VSRs were shown to block virtually all steps of RNA silencing like silencing initiation, effector phase, amplification phase, chromatin modification during TGS or modulation of host gene products for a more favorable infection. Here we review the most important strategies employed by presenting the most studied/relevant examples of VSRs (Fig. 1.1). 


\subsubsection{Blocking Initiation of Antiviral Response}

\subsubsection{Inhibition of DCL's Activities}

Initiation of silencing may be blocked by inhibition of dicing itself, either through dsRNA sequestration or through impeding DCLs or their cofactors. Pothos latent aureusvirus (PoLV) P14, TCV p38 and CMV 2b have been all shown to bind long dsRNA and thus block vsiRNA biogenesis (Deleris et al. 2006; Goto et al. 2007; Merai et al. 2005). The nuclear localized P6 suppressor of CaMV diminishes dicing through protein-protein interaction: P6 interacts with the nuclear DRB4, a cofactor required for DCL4-dependent vsiRNA processing (Haas et al. 2008). In addition, during CaMV infection massive amounts of vsiRNAs derive from the $35 \mathrm{~S}$ leader sequence recognized by all four DCLs. 35S leader RNA therefore serves as decoy to divert the effectors of the silencing machinery from more important viral features (Blevins et al. 2011). Red clover necrotic mosaic virus (RCNMV) recruits DCL enzymes into its replication complex and therefore deprives them from the silencing machinery. dcll mutant plants are less susceptible to RCNMV infection (Takeda et al. 2005). Similar strategies were described in insect-infecting viruses (Bronkhorst and van Rij 2014).

Viruses may modulate endogenous regulatory pathways in order to alter the strength of silencing in their favor. RNASE THREE_LIKE 1 (RTL1) enzyme was described as and endogenous silencing suppressor: RTL1 is induced during virus infections and prevents vsiRNA production by cleaving viral dsRNAs prior to DCL2/3/4-processing but does not interfere with DCL1-mediated miRNA pathway (Shamandi et al. 2015).

\subsubsection{2 vsiRNA Sequestration}

Ds-siRNA sequestration is a widespread strategy used by several VSRs originating from diverse genera (P19, Hc-Pro, P21, p15, p122/p126/p130, $\gamma \mathrm{B}$, NS3, NSs, Pns10 etc.) (Csorba et al. 2007; Harries et al. 2008; Hemmes et al. 2007; Kubota et al. 2003; Lakatos et al. 2006; Merai et al. 2005, 2006; Silhavy et al. 2002). Amongst these, probably the best known is the tombusviral p19 protein (Silhavy et al. 2002). Crystallographic studies have shown that p19 homodimer acts as a molecular caliper to sequester the sRNA duplexes size-specifically (Silhavy et al. 2002; Vargason et al. 2003; Ye et al. 2003). sRNA sequestration prevents RISC assembly as shown by the heterologous in vitro Drosophila embryo extract system (Lakatos et al. 2006). It seems that p19-mediated vsiRNA sequestration affects selectively AGO1- but not AGO2-loading in $N$. benthamiana during CymRSV virus infection (Kontra et al., unpublished). It was shown that due to the structural similarly between vsiRNAs and endogenous sRNAs p19 prevents RISC-loading of endogenous sRNA species in transgenic A. thaliana and $N$. benthamiana plants (Schott et al. 2012; Kontra et al. unpublished). During 
authentic virus infections however, p19-sequestration of endogenous sRNA is not efficient (Lozsa et al. 2008; Kontra et al. unpublished). The tombusviral vsiRNAs bind more efficiently to p19 to outcompete endogenous sRNAs. The basis of vsiRNA competition, besides the massive amount of vsiRNAs, could be the structural preference of p19 for perfect ds-vsiRNAs forms (contrary to the mismatchcontaining endogenous sRNAs) (Kontra et al. unpublished).

A consequence of sRNA binding by VSRs is the block of HEN1-dependent methylation of sRNAs (Csorba et al. 2007; Lozsa et al. 2008; Vogler et al. 2007). When sequestered, the methylation of sRNAs is inhibited (Csorba et al. 2007; Lozsa et al. 2008). Whether blocking of vsiRNA methylation leads to a faster decay and this has any biological significance remains a question.

It was shown that Sweet potato chlorotic stunt crinivirus (SPCSV) suppressor RNase 3 cleaves the 21-24 nt vsiRNAs into 14 bp products rendering them inactive (Cuellar et al. 2009; Kreuze et al. 2005). Although this is a completely different strategy to siRNA-binding, it has a very similar outcome: vsiRNAs are unavailable for AGO-loading.

\subsubsection{Blocking Systemic Silencing}

Although p19 sequesters vsiRNAs very efficiently, its effect to block cellautonomous silencing and restrict virus replication is mild. The VSR-deficient CymRSV (Cym19stop) replicates as efficiently as the wild type CymRSV in $N$. benthamiana protoplasts (Silhavy et al. 2002). The true strength of p19 lies in blocking systemic silencing through inhibition of vsiRNA mobilization into naive surrounding tissue or long distance (Dunoyer et al. 2010; Havelda et al. 2003; Molnar et al. 2010). RNA binding suppressors NS3 (RSV) and 2b (CMV) were also shown to prevent efficiently the spread of silencing signal (Guo and Ding 2002; Xiong et al. 2009).

\subsubsection{Interfering with AGO-Loading}

An efficient arrest of silencing initiation can be achieved through the block of functional RISC assembly. P0 the suppressor of Poleroviruses (Mayo and ZieglerGraff 1996) was shown to enhance the degradation of effector AGOs (AGO1, 2, 4-6, 9) by inhibition of holo-RISC assembly (Baumberger et al. 2007; Bortolamiol et al. 2007; Csorba et al. 2010; Derrien et al. 2012; Pazhouhandeh et al. 2006) P0-mediated AGO degradation occurs through autophagy pathway (Derrien et al. 2012). ToRSV CP, that acts as a VSR as well, binds to AGO1 to suppress its translational inhibitory activity and to enhance AGO1 degradation through autophagy (Karran and Sanfacon 2014). It was shown that PVX p25 physically interacts with multiple AGOs (AGO1, 2, 3 and 4) to promote their destabilization in a proteasome-dependent manner (Chiu et al. 2010). In the absence of central AGO effector, silencing cannot be programmed/initiated. 
VSRs are able to modulate AGO1 availability in a more subtle way. AGO1 homeostasis depends on the miR168-guided AGO1 mRNA cleavage and translational inhibition control (Mallory and Vaucheret 2009; Rhoades et al. 2002). To counteract AGO1-based defense a number of unrelated siRNA-binder VSRs (p19, p122, p38, Hc-Pro and 2b) promote miR168 transcriptional induction that results in miR168-guided AGO1 down-regulation to create a better environment for virus infection. It was shown that (during tombusvirus infection) the miR168 accumulation spatially correlated with the virus localization and was dependent on the presence of p19 (Varallyay and Havelda 2013; Varallyay et al. 2010).

\subsubsection{Arrest of Programmed RISC Activity}

The Sweet potato mild mottle ipomovirus (SPMMV) suppressor protein P1 interacts directly with siRNA and/or miRNA-loaded AGO1 present in the high molecular weight holo-RISC but not minimal-RISC through GW/WG-motifs (AGO-hook) and inhibits si/miRNA-loaded RISC activity. The GW/WG-motif containing proteins (GW182 family) were shown to interact with AGOs and support diverse RISC functions (Eulalio et al. 2009). P1 AGO-hook motifs are necessary for both binding and suppression of AGO1 function (Giner et al. 2010; Szabo et al. 2012).

P38 of TCV (Azevedo et al. 2010) and 2b of CMV (Zhang et al. 2006) and Tomato aspermy virus (TAV) (Chen et al. 2008) suppressors were proposed to act at multiple steps of silencing (during initiation and effector phase) including RISC activity block through AGO protein interaction.

The block of effector step can be achieved also through targeting the RNA component (the guide vsiRNA) within the vsiRISC. African cassava mosaic virus (ACMV) encoded AC4 is able to bind to the ss- but not ds-sRNA forms in vitro. Transgenic AC4 decreases accumulation of miRNAs and up-regulates target mRNAs. AC4 acts downstream of the unwinding process by binding miRNAs presumably loaded into AGO (Chellappan et al. 2005; Xiong et al. 2009; Zhou et al. 2006). RSV suppressor NS3 was found to bind to various RNA forms like ss-siRNA, ds-siRNA or long ssRNA (but not long dsRNA). By this, NS3 is able to suppress and revert local silencing but also prevent the long distance spread of silencing signal (Chellappan et al. 2005; Xiong et al. 2009; Zhou et al. 2006). Similarly, Grapevine virus A (GVA) p10 suppressor was also suggested to act through both ss- and ds-si/miRNA binding (Chellappan et al. 2005; Xiong et al. 2009; Zhou et al. 2006).

\subsubsection{VSR Activities Affecting TGS}

Several DNA viruses encode VSRs that have been described to alter the effector step of TGS, the chromatin structure modification. AL2 suppressor of Tomato golden mosaic virus (TGMV) and L2 suppressor of Beet curly top virus (BCTV) 
inhibit adenosine kinase (ADK) activity that plays crucial role in adenosine and methyl-cycle maintenance or cytokinin regulation. AL2 and L2 induce global reduction in cytosine methylation that leads to inactivation and reversal of antiviral silencing (Buchmann et al. 2009; Wang et al. 2003, 2005). In vitro methylated TGMV cannot replicate in protoplasts suggesting that viral genome methylation is a bona fide defense against geminiviruses (Bisaro 2006). Similarly, BC1 suppressor of Tomato yellow leaf curl China virus (TYLCCNV) interacts and inhibits activity of S-adenosyl-homocystein-hydrolase (SAHH) that is involved in methyl-cycle and therefore indirectly affects TGS (Yang et al. 2011).

\subsubsection{Suppression of Antiviral Silencing Amplification}

Blocking RDR activities by VSRs is a very effective strategy employed by viruses since it dampens cell-autonomous silencing amplification and systemic signal movement in distant tissues to facilitate the virus replication and spread (Ren et al. 2010; Schwach et al. 2005). V2 suppressor of TYLCV inhibits RDR6mediated amplification by direct interaction with SGS3, the cofactor of RDR6 (Glick et al. 2008). Alternatively, V2 may compete with SGS3 for dsRNA having $5^{\prime}$ overhang ends that may be an RDR6/SGS3 substrate/intermediate during vsiRNA amplification (Fukunaga and Doudna 2009; Kumakura et al. 2009). Similarly, TRIPLE GENE BOX PROTEIN1 (TGBp1) encoded by PVX was shown to inhibit RDR6/SGS3-dependent dsRNA synthesis (Okano et al. 2014). $\beta C 1$ suppressor of TYLCCNV DNA satellite interacts with the endogenous suppressor of silencing calmodulin-like protein ( $\mathrm{rgsCAM}$ ) in $N$. benthamiana to repress RDR6 expression (Li et al. 2014). SCMV encoded HC-Pro, TAV 2b and Pns 10 of RDV were all shown to downregulate RDR6 to limit amplification and decelerate systemic silencing (Ren et al. 2010; Zhang et al. 2008). Plant RDR1 however, was suggested to have adverse functions: RDR1 is an antagonist of RDR6-mediated sense-PTGS making it an endogenous silencing suppressor (Ying et al. 2010).

\subsubsection{Targeting Multiple Steps of Antiviral Pathways}

Many VSRs have multiple silencing suppressor functions and therefore are capable to act at multiple points to modulate antiviral response. 2b of CMV (CM95R strain) and TAV exhibit high affinity for long dsRNAs and ds-sRNAs (Chen et al. 2008; Duan et al. 2012; Gonzalez et al. 2012; Goto et al. 2007). CMV 2b (Fny and SD strains) was also shown to interact with AGO1 through the PAZ- and partly PIWI domains and blocks RISC slicer activity (Duan et al. 2012; Zhang et al. 2006). Additionally, CMV 2b (SD strain) alters RdDM pathway as well. 2b facilitates cytosine methylation through the transport of siRNAs into the nucleus (Kanazawa et al. 2011). 2b interacts both with AGO4-related siRNAs and with AGO4 protein 
through PAZ and PIWI domains. The interaction with $2 \mathrm{~b}$ reduces AGO4 access to endogenous target loci and consequently modulates endogenous transcription to create a favorable niche for CMV infection (Duan et al. 2012; Gonzalez et al. 2010, 2012; Hamera et al. 2012).

P38 of TCV may also suppress silencing at multiple levels. P38 possesses dsRNA-binding activity (Merai et al. 2006). Since in the presence of p38, siRNAs are undetectable therefore it was proposed that $\mathrm{p} 38$ suppress DCLs' activity (Qu et al. 2003). Genetic evidences also supported the role of p38 in inhibiting DCL4 (Deleris et al. 2006). In a later study however, p38 suppressor impact on DCL4 was attributed to an indirect effect of AGO1-mediated DCL-homeostasis and has been shown that $\mathrm{p} 38$ blocks AGO1 but not AGO4 activity through its GW-motif binding (Azevedo et al. 2010). P38 is capable to bind and inactivate AGO2 as well (Zhang et al. 2012). Site-directed mutagenesis (GW-to-GA) in the p38 proved that GW motif is absolutely required for both binding and suppression of AGO1 function (Azevedo et al. 2010). Pelargonium line pattern virus (PLPV) coat protein p37 (an orthologue of TCV p38) is a GW-containing protein that functions as a VSR as well. It was shown that the mutations within its GW-motif affect p37 localization, interaction with AGO1 and its sRNA-binding ability. Furthermore, GW-mutations also abolished TCV p38 sRNA and long dsRNA-binding capacity (Perez-Canamas and Hernandez 2015). It seems therefore that the domain for different functions may overlap in p37/p38 VSRs. This brings up the possibility that the parallel suppressor functions could cooperate during their interaction with host silencing machinery (e.g. p37/p38 interaction with AGO1 could enhance sRNA duplex sequestration in order to more efficiently prevent RISC programming).

\subsubsection{VSRs' Interaction with Host Factors to Modulate Silencing}

Besides blocking antiviral silencing VSRs are able to modulate host endogenous pathways in order to fine-tune the host-pathogen interaction. The suppressor of Tobacco etch virus (TEV) helper-component protease (HC-Pro) is a multifunctional protein involved in many aspects of virus infection (Anandalakshmi et al. 1998; Carrington et al. 1989; Guo et al. 2011; Kasschau et al. 1997; Lakatos et al. 2006; Mallory et al. 2001). HC-Pro sequesters vsiRNA that leads to inhibition of their methylation and inability to load into vsiRISC (Lakatos et al. 2006; Lozsa et al. 2008). HC-Pro was also found to interact with rgsCAM an endogenous silencing suppressor (Anandalakshmi et al. 2000; Endres et al. 2010; Marquardt et al. 2014). In another study it was shown that rgsCAM counteracts HC-Pro through binding to its positively charged dsRNA-binding surface, prevents HC-Pro siRNA-sequestration and promotes HC-Pro degradation through autophagy pathway (Nakahara et al. 2012). Suppression of silencing by 
TuMV HC-Pro requires another host factor, RAV2, a transcription factor. RAV2 targets include FIERYI and CML38, endogenous suppressors of silencing (Anandalakshmi et al. 2000; Endres et al. 2010; Gy et al. 2007). RAV2 was required for suppression of silencing by Carmoviral p38 as well (Endres et al. 2010) suggesting that RAV2 is a cross-talk point between antiviral and endogenous silencing pathways, and may be efficiently used by suppressors to modulate host defense. HC-Pro of another potyvirus, Papaya ringspot virus (PRSV), interacts with calreticulin to modulate calcium signaling and thus host defense (Shen et al. 2010a, b). HC-Pro (of Potato virus A (PVA), Potato virus $Y$ (PVY) and TEV) interacts also with microtubule-associated protein (HIP2) through its highly variable region (HVR). Virus accumulates at lower level when HIP2 is depleted. Mutations affecting HC-Pro HIP2 interaction induces necrosis and hormone (ethylene- and jasmonic acid-) mediated induction of host pathogen-related defense genes (Haikonen et al. 2013a, b).

\subsection{7 vsiRNAs May Regulate Host Genes by Exploiting Endogenous Silencing Itself}

The high sequence variability of vsiRNAs and the fast evolution of viral genomes, may lead to the production of vsiRNAs that could potentially target endogenous genes/transcripts. By this, viruses may modulate host response to their benefit. There are a few examples to support this idea. vsiRNAs derived from the CMV-Y satellite RNA (Y-Sat) targets magnesium protoporphyrin chelatase subunit I (CHLI), a key component of chlorophyll biosynthesis pathway. vsiRNA-mediated downregulation of CHLI mRNA leads to yellowing of the plant leaves, that was suggested to enhance virus spreading by insects (Shimura et al. 2011). sRNA derived from Peach latent mosaic viroid (PLMVd) targets chloroplastic heatshock protein 90 (cHSP90) in peach. Cleavage of cHSP90 (that participates in chloroplast biosynthesis and plasmid-nucleus signal transduction) induces albinism and may contribute to a more favorable host environment for viroid infection (Navarro et al. 2012). Callose synthase genes encode proteins with role in callose formation during pollen development. Potato spindle tuber viroid (PSTVd)-derived sRNAs suppress CalS11-like and CalS12-like mRNAs that greatly affects the severity of disease symptoms (Adkar-Purushothama et al. 2015).

\subsection{Perspectives}

With the advancement of high throughput technologies the in-depth profiling of vsiRNA generation, their loading into effectors (vsiRISC or RDR complexes) and their involvement in systemic signaling of RNA silencing will lead to a more and 
thorough understanding of antiviral defense at cellular, tissue and organism level. In addition to this, the development of novel in vitro systems and in vivo cellular assays hopefully will make it possible to better understand the mechanistic details at molecular level. The interaction of host with viral pathogens is very complex: the exact details such as how, when, and where in the cell viral RNAs are initially accessed by the RNA silencing machinery and how VSRs counteract silencing response remain elusive. It was recently reported that potyvirus-induced granules (PG) protects PVA viral RNA from antiviral silencing when active viral translation does not occur optimally (Hafren et al. 2015). Antiviral silencing, translation and RNA quality control pathways, alongside with general RNA degradation pathways all compete for endogenous and viral RNAs (Christie et al. 2011). How exactly these pathways share substrates and cooperate during viral infection will be hopefully addressed by further research.

Until recently most studies on antiviral silencing were conducted in the model Arabidopsis due to the plethora of genetic tools available. The use of Arabidopsis, however, has a major drawback since this plant model hosts only very few plant viruses. Availability of the full genome sequence of the viral model plant Nicotiana benthamiana (sensitive to almost all plant viruses) and the development of CRIPSR/CAS9 genome editing technology will hopefully allow the study of antiviral RNA silencing during several other virus infections.

An important aim of antiviral silencing research is to gather knowledge in order to be able to design resistant crops. Great advances have been made to develop methods for viral disease control with the expression of artificial sRNAs/miRNAs targeting viral genomes in economically important plants (Kis et al. 2016; Lin et al. 2009; Niu et al. 2006). Similar biotechnological approaches may be very useful to elaborate in the future for economically important crop protection.

Acknowledgements This work was supported by the Országos Tudományos Kutatási Alapprogramok-NK105850, K112737 and the János Bolyai Research Scholarship of the Hungarian Academy of Sciences. We thank Péter Gyula for useful comments on the manuscript. We apologize to those colleagues whose work was not cited due to space limitations.

\section{Glossary}

RNAi: $\quad$ RNA interference

TGS: $\quad$ Transcriptional Gene Silencing

PTGS: $\quad$ Post Transcriptional Gene Silencing

SRNA: $\quad$ small RNA

dsRNA: double-stranded RNA

ssRNA: $\quad$ single-stranded RNA

DCL: $\quad$ Dicer-Like enzymes

PAZ: Piwi/Argonaute/Zwille-domain 
AGO: $\quad$ Argonaute protein

RDR: $\quad$ RNA-dependent RNA polymerase

RISC: $\quad$ RNA-Induced Silencing Complex

RITSC: $\quad$ RNA-Induced Transcriptional Silencing Complex

miRNA : micro RNA

siRNA: $\quad$ small interfering RNA

ta-siRNA: trans-acting small interfering RNA

nat-siRNA: natural-antisense small interfering RNA

ra-siRNA: repeat-associated small interfering RNA

vsiRNA: viral small interfering RNA

vasiRNA: virus-activated small interfering RNA

\section{(+) ssRNA Virus}

BMV: $\quad$ Brome mosaic virus

CMV: $\quad$ Cucumber mosaic virus

CNV: $\quad$ Cucumber necrosis virus

CymRSV: Cymbidium ringspot virus

GVA: $\quad$ Grapevine virus A

ORMV: $\quad$ Oilseed rape mosaic virus

PLPV: $\quad$ Pelargonium line pattern virus

PoLV: $\quad$ Pothos latent virus

PRSV: $\quad$ Papaya ringspot virus

PVA: $\quad$ Potato virus A

PVX: $\quad$ Potato virus $X$

PVY: $\quad$ Potato virus $Y$

RCNMV: $\quad$ Red clover necrotic mosaic virus

RYMV: $\quad$ Rice yellow mottle virus

SCMV: $\quad$ Sugarcane mosaic virus

SPCSV: $\quad$ Sweet potato chlorotic stunt virus

SPMMV: $\quad$ Sweet potato mild mottle virus

TAV: $\quad$ Tomato aspermy virus

TEV: $\quad$ Tobacco etch virus

TBSV: $\quad$ Tomato bushy stunt virus

TCV: $\quad$ Turnip crinkle virus

TMV: $\quad$ Tobacco mosaic virus

ToRSV: $\quad$ Tomato ringspot virus

TRV: $\quad$ Tobacco rattle virus

TuMV: $\quad$ Turnip mosaic virus

TYMV: $\quad$ Turnip yellow mosaic virus 


\section{(一) ssRNA Virus}

RSV: $\quad$ Rice stripe virus

TSWV: Tomato spotted wilt virus

\section{dsRNA Virus}

OsEV: Oryza sativa endornavirus

RDV: Rice dwarf phytoreovirus

\section{ssDNA Virus}

ACMV: $\quad$ African cassava mosaic virus

BCTV: $\quad$ Beet curly top virus

CaLCuV: $\quad$ Cabbage leaf curl virus

TGMV: $\quad$ Tomato golden mosaic virus

TYLCV: $\quad$ Tomato yellow leaf curl virus

TYLCCNV: Tomato yellow leaf curl China virus

\section{dsDNA Virus}

CaMV: $\quad$ Cauliflower mosaic virus

TVCV: Turnip vein-clearing virus

viroid: non-protein coding infectios RNAs

PLMVd: Peach latent mosaic viroid

PSTVd: Potato spindle tuber viroid

\section{References}

Adenot X, Elmayan T, Lauressergues D, Boutet S, Bouche N, Gasciolli V, Vaucheret H (2006) DRB4-dependent TAS3 trans-acting siRNAs control leaf morphology through AGO7. Curr Biol 16:927-932

Adkar-Purushothama CR, Brosseau C, Giguere T, Sano T, Moffett P, Perreault JP (2015) Small RNA Derived from the Virulence Modulating Region of the Potato spindle tuber viroid Silences callose synthase Genes of Tomato Plants. Plant Cell 27:2178-2194 
Ahlquist P (2002) RNA-dependent RNA polymerases, viruses, and RNA silencing. Science 296:1270-1273

Akbergenov R, Si-Ammour A, Blevins T, Amin I, Kutter C, Vanderschuren H, Zhang P, Gruissem W, Meins F Jr, Hohn T, Pooggin MM (2006) Molecular characterization of geminivirus-derived small RNAs in different plant species. Nucleic Acids Res 34:462-471

Allen E, Xie Z, Gustafson AM, Carrington JC (2005) microRNA-directed phasing during transacting siRNA biogenesis in plants. Cell 121:207-221

Anandalakshmi R, Pruss GJ, Ge X, Marathe R, Mallory AC, Smith TH, Vance VB (1998) A viral suppressor of gene silencing in plants. Proc Natl Acad Sci U S A 95:13079-13084

Anandalakshmi R, Marathe R, Ge X, Herr JM Jr, Mau C, Mallory A, Pruss G, Bowman L, Vance VB (2000) A calmodulin-related protein that suppresses posttranscriptional gene silencing in plants. Science 290:142-144

Andika IB, Maruyama K, Sun L, Kondo H, Tamada T, Suzuki N (2015) Different Dicer-like protein components required for intracellular and systemic antiviral silencing in Arabidopsis thaliana. Plant Signal Behav 10:e1039214

Aregger M, Borah BK, Seguin J, Rajeswaran R, Gubaeva EG, Zvereva AS, Windels D, Vazquez F, Blevins T, Farinelli L, Pooggin MM (2012) Primary and secondary siRNAs in geminivirusinduced gene silencing. PLoS Pathog 8:e1002941

Azevedo J, Garcia D, Pontier D, Ohnesorge S, Yu A, Garcia S, Braun L, Bergdoll M, Hakimi MA, Lagrange T, Voinnet O (2010) Argonaute quenching and global changes in Dicer homeostasis caused by a pathogen-encoded GW repeat protein. Genes Dev 24:904-915

Baumberger N, Tsai CH, Lie M, Havecker E, Baulcombe DC (2007) The Polerovirus silencing suppressor P0 targets ARGONAUTE proteins for degradation. Curr Biol 17:1609-1614

Bernstein E, Caudy AA, Hammond SM, Hannon GJ (2001) Role for a bidentate ribonuclease in the initiation step of RNA interference. Nature 409:363-366

Bhattacharjee S, Zamora A, Azhar MT, Sacco MA, Lambert LH, Moffett P (2009) Virus resistance induced by NB-LRR proteins involves Argonaute4-dependent translational control. Plant J 58:940-951

Bisaro DM (2006) Silencing suppression by geminivirus proteins. Virology 344:158-168

Blevins T, Rajeswaran R, Shivaprasad PV, Beknazariants D, Si-Ammour A, Park HS, Vazquez F, Robertson D, Meins F Jr, Hohn T, Pooggin MM (2006) Four plant Dicers mediate viral small RNA biogenesis and DNA virus induced silencing. Nucleic Acids Res 34:6233-6246

Blevins T, Rajeswaran R, Aregger M, Borah BK, Schepetilnikov M, Baerlocher L, Farinelli L, Meins F Jr, Hohn T, Pooggin MM (2011) Massive production of small RNAs from a non-coding region of Cauliflower mosaic virus in plant defense and viral counter-defense. Nucleic Acids Res 39:5003-5014

Bollman KM, Aukerman MJ, Park MY, Hunter C, Berardini TZ, Poethig RS (2003) HASTY, the Arabidopsis ortholog of exportin 5/MSN5, regulates phase change and morphogenesis. Development 130:1493-1504

Bologna NG, Voinnet O (2014) The diversity, biogenesis, and activities of endogenous silencing small RNAs in Arabidopsis. Annu Rev Plant Biol 65:473-503

Borges F, Pereira PA, Slotkin RK, Martienssen RA, Becker JD (2011) MicroRNA activity in the Arabidopsis male germline. J Exp Bot 62:1611-1620

Bortolamiol D, Pazhouhandeh M, Marrocco K, Genschik P, Ziegler-Graff V (2007) The Polerovirus F box protein P0 targets ARGONAUTE1 to suppress RNA silencing. Curr Biol 17:1615-1621

Bouche N, Lauressergues D, Gasciolli V, Vaucheret H (2006) An antagonistic function for Arabidopsis DCL2 in development and a new function for DCL4 in generating viral siRNAs. EMBO J 25:3347-3356

Boutet S, Vazquez F, Liu J, Beclin C, Fagard M, Gratias A, Morel JB, Crete P, Chen X, Vaucheret H (2003) Arabidopsis HEN1: a genetic link between endogenous miRNA controlling development and siRNA controlling transgene silencing and virus resistance. Curr Biol 13:843-848 
Branscheid A, Marchais A, Schott G, Lange H, Gagliardi D, Andersen SU, Voinnet O, Brodersen P (2015) SKI2 mediates degradation of RISC 5'-cleavage fragments and prevents secondary siRNA production from miRNA targets in Arabidopsis. Nucleic Acids Res 43:10975-10988

Brodersen P, Voinnet O (2009) Revisiting the principles of microRNA target recognition and mode of action. Nat Rev Mol Cell Biol 10:141-148

Bronkhorst AW, van Rij RP (2014) The long and short of antiviral defense: small RNA-based immunity in insects. Curr Opin Virol 7:19-28

Brosseau C, Moffett P (2015) Functional and Genetic Analysis Identify a Role for Arabidopsis ARGONAUTE5 in Antiviral RNA Silencing. Plant Cell 27:1742-1754

Buchmann RC, Asad S, Wolf JN, Mohannath G, Bisaro DM (2009) Geminivirus AL2 and L2 proteins suppress transcriptional gene silencing and cause genome-wide reductions in cytosine methylation. J Virol 83:5005-5013

Carbonell A, Carrington JC (2015) Antiviral roles of plant ARGONAUTES. Curr Opin Plant Biol 27:111-117

Carbonell A, Fahlgren N, Garcia-Ruiz H, Gilbert KB, Montgomery TA, Nguyen T, Cuperus JT, Carrington JC (2012) Functional analysis of three Arabidopsis ARGONAUTES using slicerdefective mutants. Plant Cell 24:3613-3629

Carrington JC, Freed DD, Sanders TC (1989) Autocatalytic processing of the potyvirus helper component proteinase in Escherichia coli and in vitro. J Virol 63:4459-4463

Castel SE, Martienssen RA (2013) RNA interference in the nucleus: roles for small RNAs in transcription, epigenetics and beyond. Nat Rev Genet 14:100-112

Chellappan P, Vanitharani R, Pita J, Fauquet CM (2004) Short interfering RNA accumulation correlates with host recovery in DNA virus-infected hosts, and gene silencing targets specific viral sequences. J Virol 78:7465-7477

Chellappan P, Vanitharani R, Fauquet CM (2005) MicroRNA-binding viral protein interferes with Arabidopsis development. Proc Natl Acad Sci U S A 102:10381-10386

Chen HY, Yang J, Lin C, Yuan YA (2008) Structural basis for RNA-silencing suppression by Tomato aspermy virus protein 2b. EMBO Rep 9:754-760

Chitwood DH, Nogueira FT, Howell MD, Montgomery TA, Carrington JC, Timmermans MC (2009) Pattern formation via small RNA mobility. Genes Dev 23:549-554

Chiu MH, Chen IH, Baulcombe DC, Tsai CH (2010) The silencing suppressor P25 of Potato virus $\mathrm{X}$ interacts with Argonaute1 and mediates its degradation through the proteasome pathway. Mol Plant Pathol 11:641-649

Christie M, Brosnan CA, Rothnagel JA, Carroll BJ (2011) RNA decay and RNA silencing in plants: competition or collaboration? Front Plant Sci 2:99

Creamer KM, Partridge JF (2011) RITS-connecting transcription, RNA interference, and heterochromatin assembly in fission yeast. Wiley Interdiscip Rev RNA 2:632-646

Csorba T, Bovi A, Dalmay T, Burgyan J (2007) The p122 subunit of Tobacco Mosaic Virus replicase is a potent silencing suppressor and compromises both small interfering RNA- and microRNA-mediated pathways. J Virol 81:11768-11780

Csorba T, Lozsa R, Hutvagner G, Burgyan J (2010) Polerovirus protein P0 prevents the assembly of small RNA-containing RISC complexes and leads to degradation of ARGONAUTE1. Plant J 62:463-472

Csorba T, Kontra L, Burgyan J (2015) Viral silencing suppressors: tools forged to fine-tune hostpathogen coexistence. Virology 479-480:85-103

Cuellar WJ, Kreuze JF, Rajamaki ML, Cruzado KR, Untiveros M, Valkonen JP (2009) Elimination of antiviral defense by viral RNase III. Proc Natl Acad Sci U S A 106:10354-10358

Cui X, Cao X (2014) Epigenetic regulation and functional exaptation of transposable elements in higher plants. Curr Opin Plant Biol 21:83-88

Cullen BR, Cherry S, tenOever BR (2013) Is RNA interference a physiologically relevant innate antiviral immune response in mammals? Cell Host Microbe 14:374-378

Curtin SJ, Watson JM, Smith NA, Eamens AL, Blanchard CL, Waterhouse PM (2008) The roles of plant dsRNA-binding proteins in RNAi-like pathways. FEBS Lett 582:2753-2760 
Dalmay T, Horsefield R, Braunstein TH, Baulcombe DC (2001) SDE3 encodes an RNA helicase required for post-transcriptional gene silencing in Arabidopsis. EMBO J 20:2069-2078

Deleris A, Gallego-Bartolome J, Bao J, Kasschau KD, Carrington JC, Voinnet O (2006) Hierarchical action and inhibition of plant Dicer-like proteins in antiviral defense. Science 313:68-71

Derrien B, Baumberger N, Schepetilnikov M, Viotti C, De Cillia J, Ziegler-Graff V, Isono E, Schumacher K, Genschik P (2012) Degradation of the antiviral component ARGONAUTE1 by the autophagy pathway. Proc Natl Acad Sci U S A 109:15942-15946

Diaz-Pendon JA, Li F, Li WX, Ding SW (2007) Suppression of antiviral silencing by cucumber mosaic virus $2 \mathrm{~b}$ protein in Arabidopsis is associated with drastically reduced accumulation of three classes of viral small interfering RNAs. Plant cell 19:2053-2063

Donaire L, Barajas D, Martinez-Garcia B, Martinez-Priego L, Pagan I, Llave C (2008) Structural and genetic requirements for the biogenesis of tobacco rattle virus-derived small interfering RNAs. J Virol 82:5167-5177

Donaire L, Wang Y, Gonzalez-Ibeas D, Mayer KF, Aranda MA, Llave C (2009) Deep-sequencing of plant viral small RNAs reveals effective and widespread targeting of viral genomes. Virology 392:203-214

Duan CG, Fang YY, Zhou BJ, Zhao JH, Hou WN, Zhu H, Ding SW, Guo HS (2012) Suppression of Arabidopsis ARGONAUTE1-mediated slicing, transgene-induced RNA silencing, and DNA methylation by distinct domains of the Cucumber mosaic virus $2 b$ protein. Plant cell 24:259-274

Dunoyer P, Schott G, Himber C, Meyer D, Takeda A, Carrington JC, Voinnet O (2010) Small RNA duplexes function as mobile silencing signals between plant cells. Science 328:912-916

Dzianott A, Sztuba-Solinska J, Bujarski JJ (2012) Mutations in the antiviral RNAi defense pathway modify Brome mosaic virus RNA recombinant profiles. Mol Plant Microbe Interact 25:97-106

Eamens AL, Kim KW, Curtin SJ, Waterhouse PM (2012a) DRB2 is required for microRNA biogenesis in Arabidopsis thaliana. PLoS One 7:e35933

Eamens AL, Wook Kim K, Waterhouse PM (2012b) DRB2, DRB3 and DRB5 function in a non-canonical microRNA pathway in Arabidopsis thaliana. Plant Signal Behav 7:1224-1229

Ekwall K (2004) The RITS complex-A direct link between small RNA and heterochromatin. Mol Cell 13:304-305

Endres MW, Gregory BD, Gao Z, Foreman AW, Mlotshwa S, Ge X, Pruss GJ, Ecker JR, Bowman LH, Vance V (2010) Two plant viral suppressors of silencing require the ethylene-inducible host transcription factor RAV2 to block RNA silencing. PLoS Pathog 6:e1000729

Eulalio A, Tritschler F, Izaurralde E (2009) The GW182 protein family in animal cells: new insights into domains required for miRNA-mediated gene silencing. RNA 15:1433-1442

Fagard M, Boutet S, Morel JB, Bellini C, Vaucheret H (2000) AGO1, QDE-2, and RDE-1 are related proteins required for post-transcriptional gene silencing in plants, quelling in fungi, and RNA interference in animals. Proc Natl Acad Sci U S A 97:11650-11654

Fatyol K, Ludman M, Burgyan J (2016) Functional dissection of a plant Argonaute. Nucleic Acids Res 44(3):1384-1397

Fukunaga R, Doudna JA (2009) dsRNA with $5^{\prime}$ overhangs contributes to endogenous and antiviral RNA silencing pathways in plants. EMBO J 28:545-555

Fusaro AF, Matthew L, Smith NA, Curtin SJ, Dedic-Hagan J, Ellacott GA, Watson JM, Wang MB, Brosnan C, Carroll BJ, Waterhouse PM (2006) RNA interference-inducing hairpin RNAs in plants act through the viral defence pathway. EMBO Rep 7:1168-1175

Garcia D, Garcia S, Pontier D, Marchais A, Renou JP, Lagrange T, Voinnet O (2012) Ago hook and RNA helicase motifs underpin dual roles for SDE3 in antiviral defense and silencing of nonconserved intergenic regions. Mol Cell 48:109-120

Garcia-Ruiz H, Takeda A, Chapman EJ, Sullivan CM, Fahlgren N, Brempelis KJ, Carrington JC (2010) Arabidopsis RNA-dependent RNA polymerases and dicer-like proteins in antiviral defense and small interfering RNA biogenesis during Turnip Mosaic Virus infection. Plant Cell 22:481-496 
Garcia-Ruiz H, Carbonell A, Hoyer JS, Fahlgren N, Gilbert KB, Takeda A, Giampetruzzi A, Garcia Ruiz MT, McGinn MG, Lowery N, Martinez Baladejo MT, Carrington JC (2015) Roles and programming of Arabidopsis ARGONAUTE proteins during Turnip mosaic virus infection. PLoS Pathog 11:e1004755

Gazzani S, Lawrenson T, Woodward C, Headon D, Sablowski R (2004) A link between mRNA turnover and RNA interference in Arabidopsis. Science 306:1046-1048

Ghoshal B, Sanfacon H (2014) Temperature-dependent symptom recovery in Nicotiana benthamiana plants infected with tomato ringspot virus is associated with reduced translation of viral RNA2 and requires ARGONAUTE 1. Virology 456-457:188-197

Giner A, Lakatos L, Garcia-Chapa M, Lopez-Moya JJ, Burgyan J (2010) Viral protein inhibits RISC activity by argonaute binding through conserved WG/GW motifs. PLoS Pathog 6: e1000996

Glick E, Zrachya A, Levy Y, Mett A, Gidoni D, Belausov E, Citovsky V, Gafni Y (2008) Interaction with host SGS3 is required for suppression of RNA silencing by tomato yellow leaf curl virus V2 protein. Proc Natl Acad Sci U S A 105:157-161

Gonzalez I, Martinez L, Rakitina DV, Lewsey MG, Atencio FA, Llave C, Kalinina NO, Carr JP, Palukaitis P, Canto T (2010) Cucumber mosaic virus $2 \mathrm{~b}$ protein subcellular targets and interactions: their significance to RNA silencing suppressor activity. Mol Plant Microbe Interact 23:294-303

Gonzalez I, Rakitina D, Semashko M, Taliansky M, Praveen S, Palukaitis P, Carr JP, Kalinina N, Canto T (2012) RNA binding is more critical to the suppression of silencing function of Cucumber mosaic virus $2 \mathrm{~b}$ protein than nuclear localization. RNA 18:771-782

Goto K, Kobori T, Kosaka Y, Natsuaki T, Masuta C (2007) Characterization of silencing suppressor $2 \mathrm{~b}$ of cucumber mosaic virus based on examination of its small RNA-binding abilities. Plant Cell Physiol 48:1050-1060

Guo HS, Ding SW (2002) A viral protein inhibits the long range signaling activity of the gene silencing signal. EMBO J 21:398-407

Guo B, Lin J, Ye K (2011) Structure of the autocatalytic cysteine protease domain of potyvirus helper-component proteinase. J Biol Chem 286:21937-21943

Gy I, Gasciolli V, Lauressergues D, Morel JB, Gombert J, Proux F, Proux C, Vaucheret H, Mallory AC (2007) Arabidopsis FIERY1, XRN2, and XRN3 are endogenous RNA silencing suppressors. Plant Cell 19:3451-3461

Haas G, Azevedo J, Moissiard G, Geldreich A, Himber C, Bureau M, Fukuhara T, Keller M, Voinnet O (2008) Nuclear import of CaMV P6 is required for infection and suppression of the RNA silencing factor DRB4. EMBO J 27:2102-2112

Hafren A, Lohmus A, Makinen K (2015) Formation of Potato Virus A-Induced RNA Granules and Viral Translation Are Interrelated Processes Required for Optimal Virus Accumulation. PLoS Pathog 11:e1005314

Haikonen T, Rajamaki ML, Tian YP, Valkonen JP (2013a) Mutation of a Short Variable Region in HCpro Protein of Potato virus A Affects Interactions with a Microtubule-Associated Protein and Induces Necrotic Responses in Tobacco. Mol Plant Microbe Interact 26:721-733

Haikonen T, Rajamaki ML, Valkonen JP (2013b) Interaction of the microtubule-associated host protein HIP2 with viral helper component proteinase is important in infection with potato virus A. Mol Plant Microbe Interact 26:734-744

Hamera S, Song X, Su L, Chen X, Fang R (2012) Cucumber mosaic virus suppressor $2 b$ binds to AGO4-related small RNAs and impairs AGO4 activities. Plant J Cell Mol Biol 69:104-115

Hamilton AJ, Baulcombe DC (1999) A species of small antisense RNA in posttranscriptional gene silencing in plants. Science 286:950-952

Hammond SM, Boettcher S, Caudy AA, Kobayashi R, Hannon GJ (2001) Argonaute2, a link between genetic and biochemical analyses of RNAi. Science 293:1146-1150

Han MH, Goud S, Song L, Fedoroff N (2004) The Arabidopsis double-stranded RNA-binding protein HYL1 plays a role in microRNA-mediated gene regulation. Proc Natl Acad Sci U S A 101:1093-1098 
Harries PA, Palanichelvam K, Bhat S, Nelson RS (2008) Tobacco mosaic virus 126-kDa protein increases the susceptibility of Nicotiana tabacum to other viruses and its dosage affects virusinduced gene silencing. Mol Plant Microbe Interact 21:1539-1548

Harvey JJ, Lewsey MG, Patel K, Westwood J, Heimstadt S, Carr JP, Baulcombe DC (2011) An antiviral defense role of AGO2 in plants. PLoS One 6:e14639

Havelda Z, Hornyik C, Crescenzi A, Burgyan J (2003) In situ characterization of Cymbidium Ringspot Tombusvirus infection-induced posttranscriptional gene silencing in Nicotiana benthamiana. J Virol 77:6082-6086

Hemmes H, Lakatos L, Goldbach R, Burgyan J, Prins M (2007) The NS3 protein of Rice hoja blanca tenuivirus suppresses RNA silencing in plant and insect hosts by efficiently binding both siRNAs and miRNAs. RNA 13:1079-1089

Hernandez-Pinzon I, Yelina NE, Schwach F, Studholme DJ, Baulcombe D, Dalmay T (2007) SDE5, the putative homologue of a human mRNA export factor, is required for transgene silencing and accumulation of trans-acting endogenous siRNA. Plant $\mathrm{J}$ Cell Mol Biol 50:140-148

Hiraguri A, Itoh R, Kondo N, Nomura Y, Aizawa D, Murai Y, Koiwa H, Seki M, Shinozaki K, Fukuhara T (2005) Specific interactions between Dicer-like proteins and HYL1/DRB-family dsRNA-binding proteins in Arabidopsis thaliana. Plant Mol Biol 57:173-188

Hong W, Qian D, Sun R, Jiang L, Wang Y, Wei C, Zhang Z, Li Y (2015) OsRDR6 plays role in host defense against double-stranded RNA virus, Rice Dwarf Phytoreovirus. Sci Rep 5:11324

Hutvagner G, Simard MJ (2008) Argonaute proteins: key players in RNA silencing. Nat Rev Mol Cell Biol 9:22-32

Hutvagner G, McLachlan J, Pasquinelli AE, Balint E, Tuschl T, Zamore PD (2001) A cellular function for the RNA-interference enzyme Dicer in the maturation of the let-7 small temporal RNA. Science 293:834-838

Iki T, Yoshikawa M, Nishikiori M, Jaudal MC, Matsumoto-Yokoyama E, Mitsuhara I, Meshi T, Ishikawa M (2010) In vitro assembly of plant RNA-induced silencing complexes facilitated by molecular chaperone HSP90. Mol Cell 39:282-291

Jakubiec A, Yang SW, Chua NH (2012) Arabidopsis DRB4 protein in antiviral defense against Turnip yellow mosaic virus infection. Plant J Cell Mol Biol 69:14-25

Jaubert M, Bhattacharjee S, Mello AF, Perry KL, Moffett P (2011) ARGONAUTE2 mediates RNA-silencing antiviral defenses against Potato virus $\mathrm{X}$ in Arabidopsis. Plant Physiol 156:1556-1564

Jiang L, Qian D, Zheng H, Meng LY, Chen J, Le WJ, Zhou T, Zhou YJ, Wei CH, Li Y (2012) RNA-dependent RNA polymerase 6 of rice (Oryza sativa) plays role in host defense against negative-strand RNA virus, Rice stripe virus. Virus Res 163:512-519

Kalantidis K, Schumacher HT, Alexiadis T, Helm JM (2008) RNA silencing movement in plants. Biol Cell 100:13-26

Kanazawa A, Inaba J, Shimura H, Otagaki S, Tsukahara S, Matsuzawa A, Kim BM, Goto K, Masuta C (2011) Virus-mediated efficient induction of epigenetic modifications of endogenous genes with phenotypic changes in plants. Plant J Cell Mol Biol 65:156-168

Karran RA, Sanfacon H (2014) Tomato ringspot virus coat protein binds to ARGONAUTE 1 and suppresses the translation repression of a reporter gene. Mol Plant Microbe Interact 27:933-943

Kasschau KD, Cronin S, Carrington JC (1997) Genome amplification and long-distance movement functions associated with the central domain of tobacco etch potyvirus helper componentproteinase. Virology 228:251-262

Katiyar-Agarwal S, Morgan R, Dahlbeck D, Borsani O, Villegas A Jr, Zhu JK, Staskawicz BJ, Jin $\mathrm{H}$ (2006) A pathogen-inducible endogenous siRNA in plant immunity. Proc Natl Acad Sci U S A 103:18002-18007

Khvorova A, Reynolds A, Jayasena SD (2003) Functional siRNAs and miRNAs exhibit strand bias. Cell 115:209-216 
Kim YJ, Maizel A, Chen X (2014) Traffic into silence: endomembranes and post-transcriptional RNA silencing. EMBO J 33:968-980

Kis A, Tholt G, Ivanics M, Varallyay E, Jenes B, Havelda Z (2016) Polycistronic artificial miRNA-mediated resistance to Wheat dwarf virus in barley is highly efficient at low temperature. Mol Plant Pathol 17(3):427-437

Kreuze JF, Savenkov EI, Cuellar W, Li X, Valkonen JP (2005) Viral class 1 RNase III involved in suppression of RNA silencing. J Virol 79:7227-7238

Kubota K, Tsuda S, Tamai A, Meshi T (2003) Tomato mosaic virus replication protein suppresses virus-targeted posttranscriptional gene silencing. J Virol 77:11016-11026

Kumakura N, Takeda A, Fujioka Y, Motose H, Takano R, Watanabe Y (2009) SGS3 and RDR6 interact and colocalize in cytoplasmic SGS3/RDR6-bodies. FEBS Lett 583:1261-1266

Kwak PB, Tomari Y (2012) The N domain of Argonaute drives duplex unwinding during RISC assembly. Nat Struct Mol Biol 19:145-151

Lacombe S, Bangratz M, Vignols F, Brugidou C (2010) The rice yellow mottle virus P1 protein exhibits dual functions to suppress and activate gene silencing. Plant $\mathrm{J}$ Cell Mol Biol 61:371-382

Lakatos L, Csorba T, Pantaleo V, Chapman EJ, Carrington JC, Liu YP, Dolja VV, Calvino LF, Lopez-Moya JJ, Burgyan J (2006) Small RNA binding is a common strategy to suppress RNA silencing by several viral suppressors. EMBO J 25:2768-2780

Lee YS, Nakahara K, Pham JW, Kim K, He Z, Sontheimer EJ, Carthew RW (2004) Distinct roles for Drosophila Dicer-1 and Dicer-2 in the siRNA/miRNA silencing pathways. Cell 117:69-81

Li F, Huang C, Li Z, Zhou X (2014) Suppression of RNA silencing by a plant DNA virus satellite requires a host calmodulin-like protein to repress RDR6 expression. PLoS Pathog 10:e1003921

Lin SS, Wu HW, Elena SF, Chen KC, Niu QW, Yeh SD, Chen CC, Chua NH (2009) Molecular evolution of a viral non-coding sequence under the selective pressure of amiRNA-mediated silencing. PLoS Pathog 5:e1000312

Liu J, Carmell MA, Rivas FV, Marsden CG, Thomson JM, Song JJ, Hammond SM, Joshua-Tor L, Hannon GJ (2004) Argonaute2 is the catalytic engine of mammalian RNAi. Science 305:1437-1441

Lozsa R, Csorba T, Lakatos L, Burgyan J (2008) Inhibition of 3' modification of small RNAs in virus-infected plants require spatial and temporal co-expression of small RNAs and viral silencing-suppressor proteins. Nucleic Acids Res 36:4099-4107

Ma X, Nicole MC, Meteignier LV, Hong N, Wang G, Moffett P (2015) Different roles for RNA silencing and RNA processing components in virus recovery and virus-induced gene silencing in plants. J Exp Bot 66:919-932

Maillard PV, Ciaudo C, Marchais A, Li Y, Jay F, Ding SW, Voinnet O (2013) Antiviral RNA interference in mammalian cells. Science 342:235-238

Mallory AC, Vaucheret H (2009) ARGONAUTE 1 homeostasis invokes the coordinate action of the microRNA and siRNA pathways. EMBO Rep 10:521-526

Mallory A, Vaucheret H (2010) Form, function, and regulation of ARGONAUTE proteins. Plant Cell 22:3879-3889

Mallory AC, Ely L, Smith TH, Marathe R, Anandalakshmi R, Fagard M, Vaucheret H, Pruss G, Bowman L, Vance VB (2001) HC-Pro suppression of transgene silencing eliminates the small RNAs but not transgene methylation or the mobile signal. Plant Cell 13:571-583

Mallory AC, Elmayan T, Vaucheret H (2008) MicroRNA maturation and action--the expanding roles of ARGONAUTEs. Curr Opin Plant Biol 11:560-566

Marquardt S, Raitskin O, Wu Z, Liu F, Sun Q, Dean C (2014) Functional consequences of splicing of the antisense transcript COOLAIR on FLC transcription. Mol Cell 54:156-165

Martinez de Alba AE, Elvira-Matelot E, Vaucheret H (2013) Gene silencing in plants: a diversity of pathways. Biochim Biophys Acta 1829:1300-1308

Martinez de Alba AE, Moreno AB, Gabriel M, Mallory AC, Christ A, Bounon R, Balzergue S, Aubourg S, Gautheret D, Crespi MD, Vaucheret H, Maizel A (2015) In plants, decapping 
prevents RDR6-dependent production of small interfering RNAs from endogenous mRNAs. Nucleic Acids Res 43:2902-2913

Mayo MA, Ziegler-Graff V (1996) Molecular biology of luteoviruses. Adv Virus Res 46:413-460 Merai Z, Kerenyi Z, Molnar A, Barta E, Valoczi A, Bisztray G, Havelda Z, Burgyan J, Silhavy D (2005) Aureusvirus P14 is an efficient RNA silencing suppressor that binds double-stranded RNAs without size specificity. J Virol 79:7217-7226

Merai Z, Kerenyi Z, Kertesz S, Magna M, Lakatos L, Silhavy D (2006) Double-stranded RNA binding may be a general plant RNA viral strategy to suppress RNA silencing. J Virol 80:5747-5756

Mi S, Cai T, Hu Y, Chen Y, Hodges E, Ni F, Wu L, Li S, Zhou H, Long C, Chen S, Hannon GJ, Qi Y (2008) Sorting of small RNAs into Arabidopsis argonaute complexes is directed by the $5^{\prime}$ terminal nucleotide. Cell 133:116-127

Molnar A, Csorba T, Lakatos L, Varallyay E, Lacomme C, Burgyan J (2005) Plant virus-derived small interfering RNAs originate predominantly from highly structured single-stranded viral RNAs. J Virol 79:7812-7818

Molnar A, Melnyk CW, Bassett A, Hardcastle TJ, Dunn R, Baulcombe DC (2010) Small silencing RNAs in plants are mobile and direct epigenetic modification in recipient cells. Science 328:872-875

Molnar A, Melnyk C, Baulcombe DC (2011) Silencing signals in plants: a long journey for small RNAs. Genome Biol 12:215

Morel JB, Godon C, Mourrain P, Beclin C, Boutet S, Feuerbach F, Proux F, Vaucheret H (2002) Fertile hypomorphic ARGONAUTE (ago1) mutants impaired in post-transcriptional gene silencing and virus resistance. Plant Cell 14:629-639

Moreno AB, Martinez de Alba AE, Bardou F, Crespi MD, Vaucheret H, Maizel A, Mallory AC (2013) Cytoplasmic and nuclear quality control and turnover of single-stranded RNA modulate post-transcriptional gene silencing in plants. Nucleic Acids Res 41:4699-4708

Mourrain P, Beclin C, Elmayan T, Feuerbach F, Godon C, Morel JB, Jouette D, Lacombe AM, Nikic S, Picault N, Remoue K, Sanial M, Vo TA, Vaucheret H (2000) Arabidopsis SGS2 and SGS3 genes are required for posttranscriptional gene silencing and natural virus resistance. Cell 101:533-542

Muangsan N, Beclin C, Vaucheret H, Robertson D (2004) Geminivirus VIGS of endogenous genes requires SGS2/SDE1 and SGS3 and defines a new branch in the genetic pathway for silencing in plants. Plant J Cell Mol Biol 38:1004-1014

Nakahara KS, Masuta C, Yamada S, Shimura H, Kashihara Y, Wada TS, Meguro A, Goto K, Tadamura K, Sueda K, Sekiguchi T, Shao J, Itchoda N, Matsumura T, Igarashi M, Ito K, Carthew RW, Uyeda I (2012) Tobacco calmodulin-like protein provides secondary defense by binding to and directing degradation of virus RNA silencing suppressors. Proc Natl Acad Sci U S A 109:10113-10118

Navarro B, Gisel A, Rodio ME, Delgado S, Flores R, Di Serio F (2012) Small RNAs containing the pathogenic determinant of a chloroplast-replicating viroid guide the degradation of a host mRNA as predicted by RNA silencing. Plant J Cell Mol Biol 70:991-1003

Niu QW, Lin SS, Reyes JL, Chen KC, Wu HW, Yeh SD, Chua NH (2006) Expression of artificial microRNAs in transgenic Arabidopsis thaliana confers virus resistance. Nat Biotechnol 24:1420-1428

Nonomura K, Morohoshi A, Nakano M, Eiguchi M, Miyao A, Hirochika H, Kurata N (2007) A germ cell specific gene of the ARGONAUTE family is essential for the progression of premeiotic mitosis and meiosis during sporogenesis in rice. Plant Cell 19:2583-2594

Odokonyero D, Mendoza MR, Alvarado VY, Zhang J, Wang X, Scholthof HB (2015) Transgenic down-regulation of ARGONAUTE2 expression in Nicotiana benthamiana interferes with several layers of antiviral defenses. Virology 486:209-218

Okano Y, Senshu H, Hashimoto M, Neriya Y, Netsu O, Minato N, Yoshida T, Maejima K, Oshima K, Komatsu K, Yamaji Y, Namba S (2014) In Planta Recognition of a Double- 
Stranded RNA Synthesis Protein Complex by a Potexviral RNA Silencing Suppressor. Plant Cell 26:2168-2183

Omarov RT, Ciomperlik J, Scholthof HB (2016) An in vitro reprogrammable antiviral RISC with size-preferential ribonuclease activity. Virology 490:41-48

Pantaleo V, Szittya G, Burgyan J (2007) Molecular bases of viral RNA targeting by viral small interfering RNA-programmed RISC. J Virol 81:3797-3806

Parent JS, Bouteiller N, Elmayan T, Vaucheret H (2015a) Respective contributions of Arabidopsis DCL2 and DCL4 to RNA silencing. Plant J Cell Mol Biol 81:223-232

Parent JS, Jauvion V, Bouche N, Beclin C, Hachet M, Zytnicki M, Vaucheret H (2015b) Posttranscriptional gene silencing triggered by sense transgenes involves uncapped antisense RNA and differs from silencing intentionally triggered by antisense transgenes. Nucleic Acids Res 43:8464-8475

Park MY, Wu G, Gonzalez-Sulser A, Vaucheret H, Poethig RS (2005) Nuclear processing and export of microRNAs in Arabidopsis. Proc Natl Acad Sci U S A 102:3691-3696

Pazhouhandeh M, Dieterle M, Marrocco K, Lechner E, Berry B, Brault V, Hemmer O, Kretsch T, Richards KE, Genschik P, Ziegler-Graff V (2006) F-box-like domain in the polerovirus protein P0 is required for silencing suppressor function. Proc Natl Acad Sci U S A 103:1994-1999

Peragine A, Yoshikawa M, Wu G, Albrecht HL, Poethig RS (2004) SGS3 and SGS2/SDE1/RDR6 are required for juvenile development and the production of trans-acting siRNAs in Arabidopsis. Genes Dev 18:2368-2379

Perez-Canamas M, Hernandez C (2015) Key importance of small RNA binding for the activity of a glycine-tryptophan (GW) motif-containing viral suppressor of RNA silencing. J Biol Chem 290:3106-3120

Pham JW, Pellino JL, Lee YS, Carthew RW, Sontheimer EJ (2004) A Dicer-2-dependent 80s complex cleaves targeted mRNAs during RNAi in Drosophila. Cell 117:83-94

Pumplin N, Voinnet O (2013) RNA silencing suppression by plant pathogens: defence, counterdefence and counter-counter-defence. Nat Rev Microbiol 11:745-760

Qi X, Bao FS, Xie Z (2009) Small RNA deep sequencing reveals role for Arabidopsis thaliana RNA-dependent RNA polymerases in viral siRNA biogenesis. PLoS One 4:e4971

Qu F, Ren T, Morris TJ (2003) The coat protein of turnip crinkle virus suppresses posttranscriptional gene silencing at an early initiation step. J Virol 77:511-522

Qu F, Ye X, Morris TJ (2008) Arabidopsis DRB4, AGO1, AGO7, and RDR6 participate in a DCL4-initiated antiviral RNA silencing pathway negatively regulated by DCL1. Proc Natl Acad Sci U S A 105:14732-14737

Raja P, Sanville BC, Buchmann RC, Bisaro DM (2008) Viral genome methylation as an epigenetic defense against geminiviruses. J Virol 82:8997-9007

Raja P, Jackel JN, Li S, Heard IM, Bisaro DM (2014) Arabidopsis double-stranded RNA binding protein DRB3 participates in methylation-mediated defense against geminiviruses. J Virol 88:2611-2622

Reis RS, Hart-Smith G, Eamens AL, Wilkins MR, Waterhouse PM (2015) Gene regulation by translational inhibition is determined by Dicer partnering proteins. Nat Plants 1:1-6

Ren B, Guo Y, Gao F, Zhou P, Wu F, Meng Z, Wei C, Li Y (2010) Multiple functions of Rice dwarf phytoreovirus Pns10 in suppressing systemic RNA silencing. J Virol 84:12914-12923

Ren G, Xie M, Zhang S, Vinovskis C, Chen X, Yu B (2014) Methylation protects microRNAs from an AGO1-associated activity that uridylates $5^{\prime}$ RNA fragments generated by AGO1 cleavage. Proc Natl Acad Sci U S A 111:6365-6370

Rhoades MW, Reinhart BJ, Lim LP, Burge CB, Bartel B, Bartel DP (2002) Prediction of plant microRNA targets. Cell 110:513-520

Scholthof HB, Alvarado VY, Vega-Arreguin JC, Ciomperlik J, Odokonyero D, Brosseau C, Jaubert M, Zamora A, Moffett P (2011) Identification of an ARGONAUTE for antiviral RNA silencing in Nicotiana benthamiana. Plant Physiol 156:1548-1555

Schott G, Mari-Ordonez A, Himber C, Alioua A, Voinnet O, Dunoyer P (2012) Differential effects of viral silencing suppressors on siRNA and miRNA loading support the existence of two distinct cellular pools of ARGONAUTE1. EMBO J 31:2553-2565 
Schuck J, Gursinsky T, Pantaleo V, Burgyan J, Behrens SE (2013) AGO/RISC-mediated antiviral RNA silencing in a plant in vitro system. Nucleic Acids Res 41:5090-5103

Schwach F, Vaistij FE, Jones L, Baulcombe DC (2005) An RNA-dependent RNA polymerase prevents meristem invasion by potato virus $\mathrm{X}$ and is required for the activity but not the production of a systemic silencing signal. Plant Physiol 138:1842-1852

Schwarz DS, Hutvagner G, Du T, Xu Z, Aronin N, Zamore PD (2003) Asymmetry in the assembly of the RNAi enzyme complex. Cell 115:199-208

Shabalina SA, Koonin EV (2008) Origins and evolution of eukaryotic RNA interference. Trends Ecol Evol 23:578-587

Shamandi N, Zytnicki M, Charbonnel C, Elvira-Matelot E, Bochnakian A, Comella P, Mallory AC, Lepere G, Saez-Vasquez J, Vaucheret H (2015) Plants Encode a General siRNA Suppressor That Is Induced and Suppressed by Viruses. Plos Biol 13:e1002326

Shen W, Yan P, Gao L, Pan X, Wu J, Zhou P (2010a) Helper component-proteinase (HC-Pro) protein of Papaya ringspot virus interacts with papaya calreticulin. Mol Plant Pathol 11:335-346

Shen WT, Wang MQ, Yan P, Gao L, Zhou P (2010b) Protein interaction matrix of Papaya ringspot virus type $\mathrm{P}$ based on a yeast two-hybrid system. Acta Virol 54:49-54

Shimura H, Pantaleo V, Ishihara T, Myojo N, Inaba J, Sueda K, Burgyan J, Masuta C (2011) A viral satellite RNA induces yellow symptoms on tobacco by targeting a gene involved in chlorophyll biosynthesis using the RNA silencing machinery. PLoS Pathog 7:e1002021

Sijen T, Fleenor J, Simmer F, Thijssen KL, Parrish S, Timmons L, Plasterk RH, Fire A (2001) On the role of RNA amplification in dsRNA-triggered gene silencing. Cell 107:465-476

Silhavy D, Molnar A, Lucioli A, Szittya G, Hornyik C, Tavazza M, Burgyan J (2002) A viral protein suppresses RNA silencing and binds silencing-generated, 21- to 25-nucleotide doublestranded RNAs. EMBO J 21:3070-3080

Slotkin RK, Vaughn M, Borges F, Tanurdzic M, Becker JD, Feijo JA, Martienssen RA (2009) Epigenetic reprogramming and small RNA silencing of transposable elements in pollen. Cell $136: 461-472$

Souret FF, Kastenmayer JP, Green PJ (2004) AtXRN4 degrades mRNA in Arabidopsis and its substrates include selected miRNA targets. Mol Cell 15:173-183

Szabo EZ, Manczinger M, Goblos A, Kemeny L, Lakatos L (2012) Switching on RNA silencing suppressor activity by restoring argonaute binding to a viral protein. J Virol 86:8324-8327

Szittya G, Molnar A, Silhavy D, Hornyik C, Burgyan J (2002) Short defective interfering RNAs of tombusviruses are not targeted but trigger post-transcriptional gene silencing against their helper virus. Plant Cell 14:359-372

Szittya G, Moxon S, Pantaleo V, Toth G, Rusholme Pilcher RL, Moulton V, Burgyan J, Dalmay T (2010) Structural and functional analysis of viral siRNAs. PLoS Pathog 6:e1000838

Takeda A, Tsukuda M, Mizumoto H, Okamoto K, Kaido M, Mise K, Okuno T (2005) A plant RNA virus suppresses RNA silencing through viral RNA replication. EMBO J 24:3147-3157

Takeda A, Iwasaki S, Watanabe T, Utsumi M, Watanabe Y (2008) The mechanism selecting the guide strand from small RNA duplexes is different among argonaute proteins. Plant Cell Physiol 49:493-500

Tomari Y, Du T, Haley B, Schwarz DS, Bennett R, Cook HA, Koppetsch BS, Theurkauf WE, Zamore PD (2004) RISC assembly defects in the Drosophila RNAi mutant armitage. Cell 116:831-841

Urayama S, Moriyama H, Aoki N, Nakazawa Y, Okada R, Kiyota E, Miki D, Shimamoto K, Fukuhara T (2010) Knock-down of OsDCL2 in rice negatively affects maintenance of the endogenous dsRNA virus, Oryza sativa endornavirus. Plant Cell Physiol 51:58-67

Vaistij FE, Jones L, Baulcombe DC (2002) Spreading of RNA targeting and DNA methylation in RNA silencing requires transcription of the target gene and a putative RNA-dependent RNA polymerase. Plant Cell 14:857-867

Varallyay E, Havelda Z (2013) Unrelated viral suppressors of RNA silencing mediate the control of ARGONAUTE1 level. Mol Plant Pathol 14:567-575 
Varallyay E, Valoczi A, Agyi A, Burgyan J, Havelda Z (2010) Plant virus-mediated induction of miR168 is associated with repression of ARGONAUTE1 accumulation. EMBO $\mathrm{J}$ 29:3507-3519

Vargason JM, Szittya G, Burgyan J, Hall TM (2003) Size selective recognition of siRNA by an RNA silencing suppressor. Cell 115:799-811

Vogler H, Akbergenov R, Shivaprasad PV, Dang V, Fasler M, Kwon MO, Zhanybekova S, Hohn T, Heinlein M (2007) Modification of small RNAs associated with suppression of RNA silencing by tobamovirus replicase protein. J Virol 81:10379-10388

Voinnet O, Vain P, Angell S, Baulcombe DC (1998) Systemic spread of sequence-specific transgene RNA degradation in plants is initiated by localized introduction of ectopic promoterless DNA. Cell 95:177-187

Wang MB, Metzlaff M (2005) RNA silencing and antiviral defense in plants. Curr Opin Plant Biol 8:216-222

Wang H, Hao L, Shung CY, Sunter G, Bisaro DM (2003) Adenosine kinase is inactivated by geminivirus AL2 and L2 proteins. Plant Cell 15:3020-3032

Wang H, Buckley KJ, Yang X, Buchmann RC, Bisaro DM (2005) Adenosine kinase inhibition and suppression of RNA silencing by geminivirus AL2 and L2 proteins. J Virol 79:7410-7418

Wang XB, Wu Q, Ito T, Cillo F, Li WX, Chen X, Yu JL, Ding SW (2010) RNAi-mediated viral immunity requires amplification of virus-derived siRNAs in Arabidopsis thaliana. In Proceedings of the National Academy of Sciences of the United States of America 107: 484-489

Wang XB, Jovel J, Udomporn P, Wang Y, Wu Q, Li WX, Gasciolli V, Vaucheret H, Ding SW (2011) The 21-nucleotide, but not 22-nucleotide, viral secondary small interfering RNAs direct potent antiviral defense by two cooperative argonautes in Arabidopsis thaliana. Plant Cell 23:1625-1638

Wassenegger M, Krczal G (2006) Nomenclature and functions of RNA-directed RNA polymerases. Trends Plant Sci 11:142-151

Weiberg A, Jin H (2015) Small RNAs - the secret agents in the plant-pathogen interactions. Curr Opin Plant Biol 26:87-94

Wu J, Yang Z, Wang Y, Zheng L, Ye R, Ji Y, Zhao S, Ji S, Liu R, Xu L, Zheng H, Zhou Y, Zhang X, Cao X, Xie L, Wu Z, Qi Y, Li Y (2015) Viral-inducible Argonaute18 confers broadspectrum virus resistance in rice by sequestering a host microRNA. eLife 4. doi: 10.7554/eLife. 05733

Xiong R, Wu J, Zhou Y, Zhou X (2009) Characterization and subcellular localization of an RNA silencing suppressor encoded by Rice stripe tenuivirus. Virology 387:29-40

Yang Z, Ebright YW, Yu B, Chen X (2006) HEN1 recognizes 21-24 nt small RNA duplexes and deposits a methyl group onto the $2^{\prime} \mathrm{OH}$ of the $3^{\prime}$ terminal nucleotide. Nucleic Acids Res 34:667-675

Yang X, Xie Y, Raja P, Li S, Wolf JN, Shen Q, Bisaro DM, Zhou X (2011) Suppression of methylation-mediated transcriptional gene silencing by betaC1-SAHH protein interaction during geminivirus-betasatellite infection. PLoS Pathog 7:e1002329

Ye K, Malinina L, Patel DJ (2003) Recognition of small interfering RNA by a viral suppressor of RNA silencing. Nature 426:874-878

Ying XB, Dong L, Zhu H, Duan CG, Du QS, Lv DQ, Fang YY, Garcia JA, Fang RX, Guo HS (2010) RNA-dependent RNA polymerase 1 from Nicotiana tabacum suppresses RNA silencing and enhances viral infection in Nicotiana benthamiana. Plant Cell 22:1358-1372

Yoshikawa M, Peragine A, Park MY, Poethig RS (2005) A pathway for the biogenesis of transacting siRNAs in Arabidopsis. Genes Dev 19:2164-2175

Yoshikawa M, Iki T, Tsutsui Y, Miyashita K, Poethig RS, Habu Y, Ishikawa M (2013) 3' fragment of miR173-programmed RISC-cleaved RNA is protected from degradation in a complex with RISC and SGS3. Proc Natl Acad Sci U S A 110:4117-4122

Yu A, Saudemont B, Bouteiller N, Elvira-Matelot E, Lepere G, Parent JS, Morel JB, Cao J, Elmayan T, Vaucheret H (2015) Second-Site Mutagenesis of a Hypomorphic argonaute1 Allele Identifies SUPERKILLER3 as an Endogenous Suppressor of Transgene Posttranscriptional Gene Silencing. Plant Physiol 169:1266-1274 
Zhang X, Yuan YR, Pei Y, Lin SS, Tuschl T, Patel DJ, Chua NH (2006) Cucumber mosaic virusencoded $2 \mathrm{~b}$ suppressor inhibits Arabidopsis Argonaute1 cleavage activity to counter plant defense. Genes Dev 20:3255-3268

Zhang X, Du P, Lu L, Xiao Q, Wang W, Cao X, Ren B, Wei C, Li Y (2008) Contrasting effects of $\mathrm{HC}-\mathrm{Pro}$ and $2 \mathrm{~b}$ viral suppressors from Sugarcane mosaic virus and Tomato aspermy cucumovirus on the accumulation of siRNAs. Virology 374:351-360

Zhang X, Zhang X, Singh J, Li D, Qu F (2012) Temperature-dependent survival of Turnip crinkle virus-infected arabidopsis plants relies on an RNA silencing-based defense that requires dc12, AGO2, and HEN1. J Virol 86:6847-6854

Zhang X, Niu D, Carbonell A, Wang A, Lee A, Tun V, Wang Z, Carrington JC, Chang CE, Jin H (2014) ARGONAUTE PIWI domain and microRNA duplex structure regulate small RNA sorting in Arabidopsis. Nat Commun 5:5468

Zhou Z, Dell'Orco M, Saldarelli P, Turturo C, Minafra A, Martelli GP (2006) Identification of an RNA-silencing suppressor in the genome of Grapevine virus A. J Gen Virol 87:2387-2395 